\title{
LA HUELGA GENERAL DE 1917 EN LA PROVINCIA DE ALICANTE*
}

FRANCISCO MORENO SÁEZ

La huelga general de agosto de 1917 está suficientemente estudiada a nivel estatal, ${ }^{1}$ pero es muy mal conocido su desarrollo en la provincia de Alicante. Las informaciones de que disponemos sobre estos acontecimientos en Alicante suelen proceder, en general, de unos erróneos datos publicados años atrás por Fernanda Romeu y J. A. Lacomba. La excepción la constituye Vicente Ramos, que en su Historia de la provincia de Alicante y de su capital transmite unos datos muy incompletos ${ }^{2}$

* Un anticipo de este trabajo, limitado al desarrollo de la huelga en la ciudad de Alicante, fue presentado al I Congrés d'Estudis del Camp d'Alacant, en marzo de 1982.

1 Véanse las conocidas obras de M. TUÑón DE LARA, El movimiento obrero en la historia de España. Taurus. Madrid, 1972, págs. 590-600; G. H. MEAKER, La izquierda revolucionaria en España. 1914-1923. Ariel. Barcelona, 1978, páginas 119-135; J. A. LACOMBA, La crisis española de 1917. Ciencia Nueva. Madrid, 1970, págs. 213-284; FERnANDA Romeu, Las clases trabajadoras en España. Taurus. Madrid, 1970, págs. 131-143 y LuIs GómEz LLORENTE, Aproximación a la historia del socialismo español (hasta 1921). Cuadernos para el diálogo. Madrid, 1972, págs. 257-339.

2 Vicente RAmos, Historia de la provincia de Alicante y de su capital. II. Diputación Provincial. Alicante, 1971, pág. 263: "La crisis se fue generalizando y dió origen a la protesta de las clases más humildes. En la capital y durante los dias 13 al 19 de agosto de 1917, se produjo un paro colectivo. Fueron cortadas las comunicaciones ferroviarias, telegráficas y teléfonicas. Cerraron todos los establecimientos comerciales. Excepto "El Tiempo", enmudecieron los periódicos. Por las calles, vigilaban fuerzas de Infantería, Seguridad y Guardia Civil. Los tranvías marchaban bajo custodia. La ciudad se hallaba en estado de guerra. También fueron a la huelga general los obreros de Villena, Sax y Eldan. 
sobre lo aquí sucedido, que se nos presenta como algo desconectado de lo ocurrido en otros lugares del País Valenciano y de España. Fernanda Romeu ${ }^{3}$ incurrió en una confusión entre lo sucedido en la huelga ferroviaria de julio y la huelga general de agosto de 1917. Por su parte, Lacomba - autor, como es sabido, de una interesante monografía sobre la crisis de 1917- incurría en el error de mezclar hechos ocurridos en la capital de la provincia con otros acontecidos en el Alto Vinalopó: ${ }^{4}$ en todo caso, es evidente que Lacomba no utilizaba fuentes de primera mano en lo referente a lo sucedido en Alicante.

Desgraciadamente, estas parciales y confusas noticias sobre la huelga de 1917 en las comarcas del sur del País Valenciano se han consolidado como verdad histórica y han sido repetidas, año tras año, en las diversas sintesis que, sobre la historia contemporánea del País Valenciano, han sido realizadas por Manuel Cerdá, ${ }^{5}$ Manuel Ardit ${ }^{6}$ y Pedro Ruiz Torres, ${ }^{7}$ quien llega a afirmar, confundiendo de nuevo lo ocurrido en la huelga ferro-

3 Fernanda Romeu, o. c., pág. 138. Hablando de la huelga ferroviaria que se convirtió en general en Valencia, en julio de 1917, dice lo siguiente: "En algunos pueblos de Castellón y Alicante, ocurren análogos sucesos a los de Valencia. En Godelleta, Gestalfar, Buñol, reinaba la anormalidad, llegándose a proclamar la República, y en Villena y Yecla hubo verdadera resistencia a la Guardia Civil, originando gran número de heridos y algunos muertos". No hace alusión alguna a los sucesos de agosto.

4 J. A. LACOMBA, Crisi i revolució al Pais Valencià. Garbi. Valencia, 1968, página 169 , repite lo dicho por Fernanda Romeu en su tesis doctoral y reproducido en el libro ya citado sobre Las clases trabajadoras en España. En la pág. 188 y refiriéndose a los sucesos de agosto de 1917, dice lo siguiente: "Tanmateix, a Alacant es va recrudir l'agitació, i va haver-hi alguns altercats creats pels revolucionaris, que ádhuc es tirotejaren amb la guàrdia civil. La situació s'aguantá igual els dies 16 i 17, i no es va traballar ni al moll, ni a les fàbriques, ni als tallers". Cita como fuente "El Mercantil Valenciano".

5 Manuel Cerdé, Els moviments socials al País Valencià. Institució Alfons el Magnánim. Valencia. 1981, págs. 97-98, reproduce casi exactamente lo relatado por Fernanda Romeu sobre la huelga de julio y dice textualmente, refiriéndose a los acontecimientos de julio: "A Villena tingueren lloc seriosos enfrontaments amb la Guàrdia Civil que acabaren amb diversos ferits i algún mort". En cuanto a lo sucedido en agosto, Cerdá dice sobre Alicante: "Tanmateix a Alacant, l'atur durá fins el dia 17 i continuaren els xocs amb la Guàrdia Civil".

6 Manuel Ardit habla de la huelga de ferroviarios en Valencia «que en bona part conduí al fracás de la vaga general espanyola del mes d'agost". A con- 
viaria y la huelga de agosto de 1917, que la huelga de agosto -que en Asturias, por ejemplo, se prolongó durante un mes"sólo en el País Valenciano tuvo cierta consistencia".

Trataremos, pues, en este artículo, de presentar un panorama de los acontecimientos del verano de 1917 más en consonancia con la realidad, a partir de la consulta de la prensa de la época, procedimiento nada dificultoso por cierto. Como es lógico, la huelga de 1917 en Alicante no es un acontecimiento ajeno a lo ocurrido en el conjunto de España que, como se sabe, se inscribe en la que se conoce como crisis de 1917, en la que se han distinguido tres vertientes: la crisis militar provocada por las Juntas de Defensa, la crisis política que simbolizó la Asamblea Parlamentaria de Barcelona, que proponía la reunión de unas cortes constituyentes, y la huelga general misma, sobre la que vamos a centrar nuestro trabajo. ${ }^{8}$

\section{LA HUELGA GENERAL DE DICIEMBRE DE 1916}

Como consecuencia de la Guerra Mundial, "en 1916 la situación económica de todos los que viven de salarios y sueldos

tinuación sitúa también los sucesos ocurridos en Villena en agosto en esta citada huelga de julio, como hacen Romeu, Lacomba y Cerdá: "A Villena foren molt greus i hi hagué morts en els enfrontaments amb la guàrdia civil». En cuanto a los sucesos de agosto, asegura que en Alicante fueron más graves que en Valencia y que en la capital el paro duró hasta el día 17 y hubo tumultos y graves choques con la Guardia Civil, es decir, la información que proporciona Lacomba. (MANuel ARdit-Albert Balcells-NuRia Sales, Història dels Països Catalans. De 1714 a 1975. Edhasa. Barcelona, 1980.)

7 Pedro Ruiz Torres, Crisis del sistema conservador (1890-1923), en la página 290 de la Historia del País Valenciano. VI. Planeta. Barcelona, 1981, sigue también a Lacomba y confunde también, siguiendo a Romeu, la huelga ferroviaria de julio - que en algún momento sitúa en junio- con la huelga general de agosto: así dice que la huelga ferroviaria comienza el día 13 (¿de agosto?) en Valencia, al igual que en toda España, pero que el día 14 la tranquilidad volvía a ser completa. El Capitán General logró imponer el orden el día 17: "La huelga habia terminado. Era el fin del movimiento revolucionario de 1917". (!)

8 La última sintesis sobre la crisis de 1917 puede leerse en el tomo VIII de la Historia de España dirigida por M. TUÑÓN DE LARA y publicada por Labor. Barcelona, 1981. Gabriel Tortella - Casimiro Marti - José M. ${ }^{a}$ Jover - José L. Garcia DeLGado. DAvid RuIz, Revolución burguesa, oligarquía y constitucionalismo. 1834-1923. Págs. 497-502. 
se deteriora seria y progresivamente". ${ }^{9}$ Abundan los conflictos sociales en toda España, hay cierto auge de los sindicalistas y, en cambio, un reflujo de la afiliación al PSOE y a la UGT. En estas circunstancias se reúne en mayo en Madrid el XII Congreso de la UGT, que prestó especial atención a los problemas derivados del alza del coste de la vida. Los delegados asturianos, Isidoro Acevedo y Manuel Llaneza, propusieron una huelga general con este motivo, al tiempo que propugnaban una inteligencia con la CNT.

El congreso acordó una serie de medidas escalonadas: en primer lugar, reclamar del Gobierno una vez más el abaratamiento de las subsistencias (con medidas tales como fomento de obras públicas, abaratamiento de transportes, supresión de gastos improductivos, etc.); en segundo lugar, una campaña de concienciación popular sobre el problema, en colaboración "con cuantos quieran adherirse a este movimiento"; esta campaña culminaría en la celebración de reuniones y manifestaciones en un mismo dia; en tercer lugar, y si todo ello no daba resultado, estaba facultado el Comité Nacional, con el concurso de representantes regionales, para decidir, en un plazo de tres meses, un paro general de un día de duración. Si todo este plan no daba resultado, de nuevo se convocaría a los representantes de las regiones para decidir la línea a seguir. ${ }^{10}$

El Comité Nacional de la UGT visitó a Romanones, presidente del Consejo de Ministros, y le comunicó el plan escalonado. Romanones hizo una serie de promesas, que no cumpliría. Por las mismas fechas, a partir del 12 de mayo, se reunía en Valencia otro congreso, el de la CNT, en el que se llegó a semejantes conclusiones: necesidad de una campaña contra la carestía

M. TuÑón DE LaRA, o. c., pág. 577.

El texto de estos acuerdos, redactados por Besteiro, se publicó en "El Socialista", 24-V-1916. Sobre el tema, puede verse M. TUÑ́N DE LARA, O. c., págs. 578-579; J. AISA - V. M. ARBeLOA, Historia de UGT, Ed. Zero. Madrid, 1975, pág. 66; J. J. Morato, El Partido Socialista Obrero. Ayuso. Madrid, 1976 (reed.), pág. 213; L. Gómez LloRenTE, O. C., págs. 280-281; J. A. LACOMBA, o. c., pág. 41, etc. Juan Barceló, ugetista ilicitano, representaba a Levante en este comité encargado de llevar adelante la campaña. 
y de un entendimiento con los socialistas. Así las cosas, se celebra una reunión conjunta en Zaragoza entre representantes de ambas centrales sindicales: Angel Pestaña, Salvador Seguí, Largo Caballero y Vicente Barrio. Se habló ya de la fecha del 18 de diciembre para llevar a cabo la huelga general: el Gobierno reaccionó ante esta primera toma de contacto entre sindicalistas y socialistas encarcelando a varios dirigentes, cerrando Casas del Pueblo y suspendiendo las garantías constitucionales.

La campaña iba a comenzar el 16 de julio: asi, en el semanario socialista ilicitano "Trabajo" 11 aparece una nota del PSOE, que firman Anguiano y Besteiro, convocándola, y un articulo (La campaña de la UGT. Deber de disciplina) apoyando la manifestación y la campaña en general. ${ }^{12}$ El 16 de julio, en primera página, "Trabajo" anuncia la manifestación, pero en el interior da la noticia de que ha sido prohibida por el Gobierno, que ha suspendido las garantías constitucionales a raíz de la huelga de los ferroviarios. ${ }^{13}$ En Alicante, la prensa cercana a los obreros publicó también el manifiesto de la UGT ${ }^{14}$ y apoyó la idea del paro:

Que las Sociedades Obreras de Alicante se apresuren a secundar esta protesta. Hágase lo que va a hacer todo obrero consciente y así habremos cumplido con nuestro deber. ${ }^{15}$

Tras la huelga ferroviaria, en otoño se reanudaron los contactos entre la CNT y la UGT para llevar adelante la campaña. Se

11 "Trabajo", 9-VII-1916.

12 Hace memoria este artículo, que firma BASILIO, de los acuerdos del Congreso de la UGT; afirma que nada ha hecho el Gobierno salvo reprimir todas las peticiones de pan e instrucción, e informa de que las entidades domiciliadas en el Círculo Obrero Illicitano convocaban un mítin y una manifestación, pese a que en Elche todavía no se había producido la crisis de trabajo. Había que hacerlo por solidaridad "con nuestros hermanos de infortunio", olvidando "los engaños de los vampiros religiosos y capitalistas" y formando "una falange de convencidos, capaces de destruir el mundo de desigualdades".

13 "Trabajo", 16-VII-1916, afirmaba que tales medidas gubernamentales no les intimidaban: "Por al contrario, declarando nuestra completa solidaridad con los ferroviarios, cuya causa es la nuestra, nos hallamos dispuestos a hacer por éstos cuanto las circunstancias exijan, quiera o no el gobierno". "Alicante Obrero" y "Heraldo de Alicante", 6-VII-1916.

15 "Heraldo de Alicante", 7-VII-1916. 
fija la fecha del 15 de octubre para comenzar una serie de mítines y se designan oradores de las dos centrales sindicales: ${ }^{16}$ en Elche se organiza para ese mismo día una manifestación que parte del Círculo Obrero, ${ }^{17}$ a la que parece no asistió mucha concurrencia. ${ }^{18}$ "Nuevamente, ante la impasibilidad del Gobierno, se conviene en celebrar el 12 de noviembre en todo el país manifestaciones de protesta por su conducta ante las reclamaciones obreras": ${ }^{19}$ la manifestación tiene gran éxito en Elche. ${ }^{20}$ Al propio tiempo, aparecen algunos artículos en "Trabajo" que muestran la ilusión que el pacto entre la UGT y la CNT habia despertado en las bases obreras, ilusión a veces excesivamente alejada de la realidad:

Tanto los anarquistas, como socialistas, católicos, republicanos, explotados todos, nuestra misión si queremos que triunfe y que sea un hecho, cooperemos todos como un solo hombre a que la fusión del proletariado español se convierta en una realidad y habremos conseguido acercarnos más a nuestro fin deseado. Hacia la emancipación. ${ }^{21}$

16 Ante la decadencia de la nación, las miserias y calamidades que afligen a los ciudadanos y la ruindad de los gobernantes, "los trabajadores todos, prescindiendo de credos y doctrinas, hanse confabulado, han hecho una estrecha y firme unión para hacer prevalecer sus derechos de ciudadanos, para que desaparezca la pasividad y la inercia de este conglomerado de políticos que nunca se preocuparon del verdadero pueblo, del pueblo que trabaja, paga y sufre". ("Trabajo", 15-X-1916.)

17 "Vuestro deber de hombres que aspiran a que termine este estado de cosas está en acudir todos como un sólo hombre a la manifestación". ("Trabajo", 15-X-1916.)

18 "Trabajo", 29-X-1916, lamenta que los obreros no acudan a este tipo de actos.

19 AISA - ARBELOA, O. C., pág. 68 / Pro vida nacional, en "Trabajo", 12-XI-1916.

20 «Más de tres mil mujeres y otros tantos hombres se manifiestan. El mismo alcalde de la ciudad hizo causa común con los obreros, invitando al comercio a que cerrara sus puertas, y formando a la cabeza de la manifestación". ("Alicante Obrero", 24-XI-1916.) / Estupendos actos del obrero local. Mítin y manifestación, en "Trabajo", 19-XI-1916: el Teatro Llorente estuvo atestado durante el mítin y en la manifestación participaron más de seis mil obreros. Al final intervino el dirigente socialista local Vives, que mostró su satisfacción ante el comportamiento de proletariado ilicitano.

21 F. NAvARRo GonzÁLEZ, Mi grano de arena, en "Trabajo», 12-XI-1916. 
La manifestación se celebra también en Alicante, pero con escasa asistencia, al parecer. ${ }^{22}$ También se celebraron actos de esta campaña, en el mes de noviembre, en Crevillente, ${ }^{23}$ Villena ${ }^{24}$ y Alcoy. ${ }^{25}$

Poco después, una asamblea de representantes de las dos centrales sindicales ${ }^{26}$ acuerda señalar la fecha del 18 de diciembre para la huelga general de veinticuatro horas. En Alicante, aparece en la prensa ${ }^{27}$ una convocatoria - que firma el socialista Rafael Millá como secretario de la Junta de Delegados de la Casa del Pueblo- dirigida a todas las sociedades obreras para una reunión cuyo fin era organizar el paro. Anteriormente, los ferroviarios habian acordado no seguir el paro

22 "Juan sin Tierra", en "Alicante Obrero", 14-XI-1916, escribe: "Pueblo, si sabias que había una manifestación, demostraste que eres un inconsciente, un sin ideal, un sin patria, un sin fé. Alicante apático, Alicante indiferente, Alicante inconsciente" / "La manifestación obrera del domingo... no ha revestido el carácter imponente que se proponian sus organizadores. Hay que consignarlo, ya que es verdad y no conviene que el pueblo viva de ilusiones" ("Alicante Obrero", 16-XI-1916.) / "El Luchador", 13-XI-1916, atribuye el fracaso a haberse cambiado el horario de la manifestación / Para "Diario de Alicante", 14-XI-1916, hubo desidia y parecía que el problema de las subsistencias no existiese en Alicante: "Unos cuantos cientos de personas, escasos, formaban la comitiva" / Sólo "La Unión Democrática", 14-XI-1916, disiente: "El pueblo alicantino ha cumplido como bueno: nada puede echársele en el rostro".

23 Participaron la Agrupación y la Juventud Socialistas, y las sociedades de Hiladores, Tejedores y Constructores de Suelas. Al final de la manifestación hubo un mítin, donde intervinieron oradores locales y los ilicitanos Esclápez y Cañizares. ("Trabajo", 19-XI-1916.) "Alicante Obrero", 29-XI-1916.

25 "El Correo", 22-XI-1916: "Para demandar a los poderes públicos la amnistia por delitos políticos y sociales, y trabajo en obras públicas y abaratamiento de las subsistencias, el comité Pro-Campaña Nacional ha celebrado un importante acto en el espacioso local de la Federación Textil, asistiendo mucha concurrencia en la que se veía a muchas mujeres".

26 Barceló tomó parte en el mítin conjunto de la UGT y la CNT para sellar el acuerdo: afirmó que, pese al caciquismo, los trabajadores de provincias cumplirian fielmente el acuerdo adoptado: "Si el Gobierno no mete en cintura con razón a los de arriba, como lo hace sin razón con los de abajo, preparémonos para hacerle comprender que estamos hartos de sufrir". ("El Socialista", 21-XI-1916.)

27 "Alicante Obrero" y "El Noticiero", 15-XII-1916. 
toda vez que el número de asociados en la sección de Alicante apenas si alcanza a un $25 \%$ de los empleados con que cuenta la compañia: la huelga, pues, sería ineficaz para los efectos que se pretenden, puesto que el servicio habría de sufrir escasa alteración. ${ }^{28}$

La Sociedad Tipográfica hace pública, en cambio, su decisión de ir al paro. La prensa local publica el manifiesto conjunto de CNT y UGT convocando la huelga ${ }^{29}$ y se fijan pasquines por las esquinas anunciándola. ${ }^{30} \mathrm{Al}$ propio tiempo, la prensa tomaba posiciones respecto a la huelga:

- "El Luchador", republicano, aplaudía el proyecto, pero advertía que la huelga "debe ser pacífica y seria, cual corresponde a un pueblo que sabe defender sus derechos y cumplir sus deberes". ${ }^{31}$

- Para "La Unión Democrática", también republicano, la huelga era justa y "lo sorprendente es que se haya tardado tanto en llegar a este acto". ${ }^{32}$

- "Alicante Obrero", con su estilo demagógico, afirmaba: "Obrero, escucha: Pedir pan, es de mendigos; y la libertad que se pide, no es libertad. No implores a nadie, porque tienes derecho a vivir y debes vivir. Si el trabajo ennoblece', la dádiva humilla. Si consigues tu libertad, habrás conseguido bienestar para tus hijos. Cumple con tu deber el lunes, y protesta con tus compañeros del hambre que sufres". 33

- El católico "La Voz de Alicante" dedicaba su editorial a la huelga: cuando estamos en vísperas de Navidad, fecha en que se anima el tráfico mercantil, el paro causará perjuicios incalculables y molestias sin cuento, malestar, rémora al avance de la Nación y gastos. En forma alarmista, aconsejaba a las familias que viajasen antes

"Diario de Alicante", 6-XII-1916.

"Trabajo», 26-XI-1916 / "El Popular», 11-XII-1916.

"El Popular", 14-XII-1916.

"El Luchador", 16-XII-1916.

"La Unión Democrática", 16-XII-1916.

"Alicante Obrero", 16-XII-1916. 
de la fecha, que se aprovisionaran de vituallas y de lo más necesario: habrá bullanga, como dicen en Barcelona, "que traerá sin duda llanto y miseria a los hogares de los trabajadores, porque los poderosos sabrán sortear los acontecimientos y más si son de los que ocupan el poder y tienen a sus órdenes los fusiles y la censuran. ${ }^{34}$

- Para "El Día", liberal y por tanto gubernamental, el paro estaba totalmente injustificado y sería ineficaz: el gobierno trataba de aminorar los efectos de la Guerra Mundial poniendo en funcionamiento las Juntas de Subsistencias, preparando un vastísimo plan de obras públicas, tratando en fin de abaratar los productos de primera necesidad y de proporcionar trabajo a los obreros. ${ }^{35}$

- Finalmente, el independiente "La Libertad", de Elche, animaba al paro y pedía a los comerciantes que cerraran las puertas de sus establecimientos. ${ }^{36}$

El día 16, en Alicante, todas las sociedades obreras convocadas - con la citada excepción de los ferroviarios, que se limitaron a protestar por telegrama- decidieron unirse a la huelga general el lunes 18. El domingo 17 aparecen dos bandos, del Gobierno Civil y del Gobierno Militar, declarando el estado de guerra, pero son al poco tiempo retirados.

A nivel estatal, la huelga general de diciembre de 1916 fue un éxito completo. ${ }^{37}$ En la provincia de Alicante también alcanzó un señalado éxito esta movilización.

En Alicante capital, el lunes 18 no entra nadie a trabajar en el muelle, y grupos de obreros en paro se dirigen a los estableci-

"La Voz de Alicante", 14-XII-1916.

"El Día», 18-XII-1916. Los operarios de "El Día" no se sumaron a la huelga, pese al acuerdo de la Sociedad Tipográfica.

"La Libertad", 17-XII-1916.

M. Tuñón de Lara, o. c., págs. 580-581 / Fernanda Romeu, o. c., pág. 131 / Según LACOMBA, O. C., "el número de parados excedió, con mucho, al de los afiliados a las dos centrales sindicales. La huelga, como se pensó, fue general y sus promotores lograron el propósito apetecidon / Según A. PESTAÑA, Lo que aprendi en la vida, Edit. ZYX. Madrid, 1971, fue «la huelga general de 24 horas más unánime que se ha hecho en nuestro país" / Para J. J. Morato, o. c., pág. 213 , la huelga fue "general, unánime, extensa y anuncio de lo que podría ocurrir». 
mientos abiertos y piden "con muy buenos modos" que cierren, lo que hace la mayoría. No aparece prensa, salvo "El Día" -enfrentado tradicionalmente a la Sociedad Tipográfica-, que es pisoteado en las calles por los huelguistas. Por la tarde hubo cierre general de todos los establecimientos. No se trabajó en la Fábrica de Tabacos y hubo algunos incidentes sin demasiada importancia: son detenidos por coacción Vicente Gomis Hernández, caracterizado sindicalista; Francisco Martín Arrimada, que tendrá una importante participación después en la huelga de agosto de 1917; José Pomares Lillo y Bautista Boronat Gisbert; son apedreados dos tranvías en la calle de San Vicente, cuando marchaban custodiados por guardias de Seguridad; hay algunas cargas "sin grandes violencias" de las fuerzas del orden; los huelguistas obligan a fuerza de gritos y pedradas a cerrar un taller de marmolistas en el que se trabajaba y, en la calle de Sagasta, rompen la muestra de un bar que se encontraba abierto. Pero, en general, la jornada transcurrió sin incidentes: al llover, algunos manifestantes se retiraron y el comercio - pese a que algunos intentaron reabrir las puertas en alguna ocasión - cerró casi totalmente. La ciudad, empero, quedó paralizada y se consiguió así el objetivo previsto:

Paralizado el tráfico y cerradas las puertas de los establecimientos, nuestra capital presentaba un aspecto bien triste. ${ }^{38}$

En general, la prensa alicantina justificaba la protesta obrera y alababa la forma pacífica y responsable que había adoptado:

La huelga obrera de ayer en Alicante fue una exposición solemne, sensata, del poderío y cordura de los hijos del trabajo. No hubo violencias, no hubo conato de motín, no hubo algaradas... y la clase media, que también sufre como ellos, vio con simpatía su actitud respetuosa. ${ }^{39}$

La información - que no presenta diferencias de importancia en los distintos órganos de expresión- se encuentra en "El Noticiero", "El Batallador", "Periódico para todos", "Alicante Obrero", "Diario de Alicante", "La Voz de Alicante", "El Popular", "La Unión Democrática», 19-XII-1916, y "El Tiempo», 20-XII-1916 / Véase también «El Socialista», 21-XII-1916.

"Periódico para todos", 19-XII-1916. 
Bálsamo poderoso vierte en las almas asépticas (sic) ese despertar de energias y ese acopio de esfuerzos consagrados a un fin grande y redentor. ${ }^{40}$

No ha podido ser más unánime la protesta que el pueblo de Alicante ha hecho. La política de Romanones por esta vez ha fracasado en toda España. Permanecer en el Gobierno después de todo esto, es propio de Romanonesn. ${ }^{41}$

Las posturas más contrarias eran las de "El Día", para el cual la protesta era infundada ${ }^{42}$ y "La Voz de Alicante", ${ }^{43}$ para quien la mayoría de los obreros no sabía a qué se debía la huelga, que en definitiva no había sido más que fantasear un día sobre el futuro y encontrarse al día siguiente con la dura realidad: un déficit de veinticuatro horas en la producción, que repercutiría no sobre los dirigentes, sino sobre el proletariado mismo.

Para el conservador "El Tiempo", "el proletariado español ha dado una prueba de sensatez plausible», y era de esperar una gran actividad del Gobierno para resolver el grave problema de las subsistencias "porque realmente la vida es imposible para todas las clases sociales". En definitiva, la huelga, "como los hechos han demostrado, no ha tenido nada de revolucionaria ni mucho menos". 44

Algún periódico se mostraba disconforme con la moderación de la huelga: el Gobierno es inepto, su jefe un "cabeza hueca y destartaladan, algunos están ganando dinero sin control con la guerra, mientras otros «indígenas" no pueden comer porespañola había evitado que la huelga tuviera carácter revolucionario. «El Día», 19, 20 y 21-XII-1916, polemizó con "El Luchador», desde cuyas páginas Rafael Millá le había acusado de ser el único de los quince periódicos publicados en Alicante que salió a la luz pública ese día.

43 Plinio, Al margen de la vida. El paro de las 24 horas, en "La Voz de Alicante", 19-XII-1916 / Según este diario, los obreros lo más que decían para justificar el paro era que se debía a las subsistencias o a las órdenes del presidente de su sociedad obrera.

44 "El Tiempo", 19 y 20-XII-1916 / Sin embargo, para "El Tiempo", la huelga "ha sido poco menos que un fracaso en esta capital". 
que no son accionistas de bancos, ni tienen pingües intervenciones en explotaciones mineras, ni fletan barcos ni saben de dividendos ni de nóminas honoríficas ni de gabelas innombrables: en suma, "no deben ser las huelgas en nuestro país mera paralización de brazos sino viril levantamiento de puños; no debe ser inercia, sino actividad; no deben ser beatífica quietud, sino demoledora energía". La masa, que tiene hambre, "se limita platónicamente a protestar porque no sabe derribar ídolos, ni deshacer fetiches". ${ }^{45}$

En Elche el paro - que fue convocado por los socialistas y todas las sociedades obreras ${ }^{46}$ - fue total: "Ha sido Elche una de las poblaciones de España donde más se ha observado la paralización completa, absoluta, en todos los órdenes de la actividad humana. Nadie trabajó en Elche el día 18. Ni las fábricas de alpargatas, ni las de lonas, ni la de hilados; ningún taller de ninguna industria, ningún establecimiento fabril de los dedicados a tan diversas industrias trabajó ese día, con ser tantos los que aquí existen. Todos los comercios e industrias tuvieron cerradas sus puertas». ${ }^{47}$ No abrieron los cafés, no circularon los carruajes de alquiler, sólo estuvieron abiertos los estancos y las farmacias. No hubo incidentes. ${ }^{48}$ Para "La Libertad", la huelga general había supuesto "una nota más de civismo, de ciudadanía, de cultura, de sensatez y de amor a los grandes ideales de reivindicación social... un éxito grandioso". ${ }^{49}$

Editorial de "Heraldo de Alicante", que reproduce y hace suyo "El Batallador", 19-XII-1916.

46 Las sociedades Obreras en pró de la huelga general. A los trabajadores y al pueblo, hoja fechada el 16-XII-1916, que se conserva en el Archivo Municipal de Elche.

47 "La Libertad", 24-XII-1916.

48 La huelga general. Jornada memorable, en "Trabajo", 24-XII-1916. El acto fue "solemne, admirable, grande, ha sobrepujado el resultado a nuestras esperanzas". El comercio cerró, con apenas una excepción - que cita "Trabajo"-, cosa que "no nos esperábamos y esto lo confesamos ingenuamente». No acudió ni un sólo obrero a trabajar. La preparación de la huelga fue cuidadosa, jugando un gran papel las mujeres de "El Despertar Femenino". La noche anterior hubo un mítin, también muy concurrido, en el Teatro Llorente / "El Socialista», 20-XII-1916.

49 "La Libertad", 24-XII-1916, felicitaba a obreros y autoridades, y rompía una lanza por la clase media, a la que decia pertenecer, "tan vilipendiada y tan- 
En Alcoy el paro general fue casi absoluto y no hubo el menor incidente. El día anterior hubo un mítin para preparar el ambiente y el día 18 cerraron fábricas y talleres, adhiriéndose también el comercio. ${ }^{50}$ Para el semanario republicano "Fraternidad"

... la huelga del 18 demuestra patentemente que España ha salido de su marasmo, y piensa y siente porque sufre hambre y sed de justicia... Alcoy, a pesar del alarde de fuerzas desplegado, supo responder con la dignidad que le caracteriza: el orden fue completo y la misión cumplida. Sólo nos resta alentar a los organismos que integran la dirección del movimiento, para que no desmayen hasta lograr el triunfo. ${ }^{51}$

La huelga se produjo también, sin el menor incidente, en "otros pueblos industriosos" de la provincia: así, en Cocentaina, donde cerró el comercio y únicamente trabajó una fábrica de papel; en Villena, donde se efectuaron tres mítines para preparar el paro, que fue total en la localidad y en el campo; en Castalla, que de esa forma se incorporaba "al resto del movimiento obrero"; en Petrel, donde trabajaron sólo tres obreros, en una población de cinco mil almas; en Monóvar, tras un mítin de propaganda celebrado días antes; en Aspe, donde cerraron las fábricas de alpargatas, tejas, alcoholes, jabón, carruajes y ebanisterías; en Crevillente, donde comercio y trabajadores siguieron el paro; en Cañada, tras un mítin propagandístico a cargo de compañeros de Alcoy, Villena y Benejama, donde también hubo paro; en Onil, Bañeres, Novelda -con gran participación femenina-y Elda, donde actuaron de común acuerdo socialistas y sindicalistas, logrando un éxito total: ${ }^{52}$

En suma, como se puede apreciar, la huelga general de diciembre de 1916 fue un éxito en la provincia de Alicante y afectó no solamente a las grandes poblaciones, sino también a otras

tas veces ofendida por los trabajadores y ahora también maltratada en la hoja publicada por las Sociedades obreras", pero que no es abúlica, que ha secundado el paro y que, no hay que olvidarlo, ha sido "una colaboradora eficaz en la lucha por la conquista de las libertades y en contra del despotismo".

50 "La Lealtad", 21-XII-1916 / "El Socialista», 16 y 21-XII-1916.

51 "Fraternidad", 23-XII-1916.

52 "El Socialista», 20, 21, 22, 23, 24 y 25-XII-1916. 
muchas de mediano y pequeño tamaño, lo cual es, a su vez, un indicador de la fuerza del movimiento obrero alicantino en esos años.

\section{Los preparativos de la huelga general de agosto de 1917}

La misma tarde del 18 de diciembre de 1916, el ministro de la Gobernación recibia al Comité Nacional de la UGT y repetía las promesas anteriores en relación con la carestía de las subsistencias. Pero en los primeros meses de 1917 no se tomó ninguna medida efectiva, abundaron las huelgas y continuaron los contactos entre la UGT y la CNT, que culminaron en una reunión conjunta, celebrada el 27 de marzo en la Casa del Pueblo de Madrid: el Comité Nacional de la UGT y los representantes de las regiones, Angel Lacort por la Federación de Sociedades Obreras de Zaragoza, Salvador Seguí y Angel Pestaña por la CNT y la Asamblea de Sociedades Obreras de Valencia, firman un extenso manifiesto dirigido "A los trabajadores españoles y al país en general». En él, tras diversas consideraciones, se acuerda: en primer lugar, que no se encontraban satisfechas las demandas del último congreso de la UGT y de la asamblea de Valencia, y para llevarlas a efecto se imponía "que el proletariado español emplee la huelga general, sin plazo definido de terminación, como el arma más poderosa que posee para reivindicar sus derechos". En segundo lugar, que las organizaciones obreras, sin interrumpir su acción puramente reivindicativa, "procederán a la adopción de todas aquellas medidas que consideren adecuadas al éxito de la huelga general, hallándose preparados para el momento en que haya de comenzar este movimiento". $Y$ en tercer lugar, que los firmantes "se consideran en el deber", en representación de sus sociedades y sindicatos, de efectuar todos los preparativos, fijar la fecha, etc. ${ }^{53}$ La reacción del gobierno de Romanones fue muy violenta: suspendió las garantías constitucionales, ordenó la clausura de algunos centro obreros, encarceló a los firmantes del manifiesto (aunque fueron pronto puestos en libertad) y estableció la censura de prensa. ${ }^{54}$

53 Véanse las citadas obras de Tuñón de Lara, Gómez Llorente, Lacomba, RoMEU, Morato, etc. El texto del manifiesto puede leerse en GómEz LLORENTE, o. C., páginas 287-291.

54 «El Socialista», 29-III-1917. 
En la provincia de Alicante estos acontecimientos tuvieron las naturales repercusiones. Ya a primeros de marzo, "Trabajo" recordaba el problema de las subsistencias, que seguía en pie; que el Gobierno cobarde e inepto nada había hecho por resolverlo

... porque aquí, en este desdichado país, se anteponen a los intereses generales de la nación los particulares de los plutócratas, acaparadores y grandes capitalistas, de cuyos intereses y voluntad no pueden prescindir los que dirigen los altos destinos del pueblo". ${ }^{55}$

Otros artículos en números sucesivos ${ }^{56}$ insistían sobre la gravedad del problema. Al mismo tiempo, Juan Barceló realizaba una activa campaña en toda la zona de Levante en que la UGT tenía cierta influencia - en su mayoría, localidades ligadas a la Federación Nacional de Obreros Alpargateros - para concienciar a los obreros sobre el tema: ${ }^{57}$ viajó durante el mes de marzo a Aspe, Novelda, ${ }^{58}$ Petrel, Villena, ${ }^{59}$ Yecla, Fuente la Higuera, Vall de Uxó, Castellón, Burriana, Valencia, Sueca, Gandía, Alcoy y Almansa, no pudiendo viajar a Villarreal, Cullera y Alcira por falta de tiempo y siendo prohibida una reunión en Carcagente por las autoridades. ${ }^{60}$

A fines de marzo se suspenden las garantías constitucionales ${ }^{61}$ y es clausurado en la capital el Centro de Sociedades Obreras de la Avenida de Zorrilla - cercano a la CNT-, por or-

55

56 La situación en España. Cada dia peor, en "Trabajo", 11-III-1917 / Las subsistencias y la crisis de trabajo. El mal se agrava, en "Trabajo", 18-III-1917. La solución está en las medidas propuestas por los socialistas, que pueden parecer radicales, pero son imprescindibles.

57 Las Sociedades Obreras de Elche comisionaron a Barceló para esta campaña y "hacer un estudio de la situación y necesidades de la clase trabajadora en todas las comarcas». ("El Socialista», 8-III-1917.)

Donde el público expresó "su decisión de secundar los acuerdos de la UGT». ("El Socialista», 11-III-1917.)

59 Barceló "dió buenas impresiones sobre la situación de ánimo de los trabajadores organizados" de Villena. ("El Socialista", 22-III-1917.)

60 "Trabajo", 18 y 25-III-1917.

61 "Boletín Oficial de la Provincia», 29-III-1917. 
den gubernativa. ${ }^{62}$ En Elche, el alcalde comunicó esta suspensión y la previa censura de prensa el día 31: "Trabajo" no pudo salir porque ya tenía impresa la primera página con un artículo que no superó la censura. ${ }^{63}$ Asimismo, fue clausurado el Círculo Obrero Illicitano, cobrándose las cuotas de las sociedades obreras en el Teatro Llorente. ${ }^{64}$

La censura de prensa se ejerció duramente: así, "Trabajo" en edición del 15 de abril aparece con la primera página casi en blanco: incluso una cosa tan nimia como el servicio médico del Círculo Obrero Illicitano aparece sin el nombre de dicho Círculo. En el número del 22 de abril aparece el manifiesto del PSOE ante la situación también censurado, y un artículo, mutilado, ${ }^{65}$ en que se advierte que estas medidas represivas a nada conducian, si no era a crear un estado de ánimo más exaltado: "como epidemia aterradora corren ahora aires de redención de un ámbito a otro del planeta».

En la capital, la prensa también sufrió los estragos de la censura. "El Luchador" informaba de que la censura "prohibe publicar noticias de la huelga, comentarios sobre la actitud de los obreros, la actitud del Gobierno y sus medidas, hablar de la neutralidad y determinados comentarios sobre la guerran; ${ }^{66}$ publicaba en ocasiones información oficial; ${ }^{67}$ intentó -aunque la censura lo dejó mutilado- publicar el manifiesto conjunto de UGT y CNT el 11 de abril, concluyendo que, si se hubiese actuado con energía

... los estupendos negocios que han realizado unos cuantos favorecidos y privilegiados, habrian sido en beneficio general. Han en-

62 "La Unión Democrática», 30-III-1917.

63 "Trabajo", 8-IV-1917.

64 Permaneció cerrado el Círculo Obrero Illicitano desde el 30 de marzo al 20 de abril. ("El Socialista, 24-IV-1917.)

65 Compás de espera, en "Trabajo", 22-IV-1917 / "El Socialista", 24-IV-1917, afirma que la censura no permitía a "Trabajo" la publicación de artículos tolerados en otros periódicos.

66 "El Luchador", 31-III-1917.

67 "El día de hoy ha transcurrido con absoluta tranquilidad y completa normalidad en todas partes", asegura el telegrama del ministro de la Gobernación al Gobernador Civil. ("El Luchador», 2-IV-1917.) 
trado muchos, muchísimos millones en España, pero se han distribuido mal, y mientras unos pocos han conseguido una rápida opulencia, los más no encuentran dónde ni cómo ganar un jornalm. ${ }^{68}$

Para "El Correo", maurista, si bien era cierto que las repercusiones de la guerra habian sido grandes y las circunstancias eran precarias "para todos" y se agravaba el problema de las subsistencias

... la huelga general, de duración indefinida, es un procedimiento contraproducente para el remedio de la grave crisis social por que atraviesa la nación». 69

Finalmente, "El Tiempo" -en artículo también casi totalmente censurado - hablaba de que existía una doble responsabilidad, pues "los desapasionados y los sensatos desaprueban la actitud de los obreros y la del Gobierno". ${ }^{70}$

El 19 de abril, Garcia Prieto sustituia a Romanones en el Gobierno, tras restablecerse la normalidad constitucional.

Como hemos dicho, esta agitación coincidió en la primera mitad de 1917 con la problemática planteada por las Juntas de Defensa militares y con la lucha de las izquierdas y de los nacionalistas catalanes por un mayor protagonismo en el Parlamento, que culminaria en la asamblea parlamentaria de julio celebrada en Barcelona. Es decir, con lo que en la historiografía española se suele denominar la crisis de 1917, crisis en realidad más aparente que real, pues los intereses defendidos por las distintas fuerzas que en esos meses se enfrentan al Gobierno o al sistema eran muy dispares, lo que impedirá un cambio inmediato y decisivo en el sistema español.

Entre tanto, los dirigentes del PSOE y de la UGT se habian reunido y habían nombrado un comité - formado por Besteiro, Largo Caballero, Torralba Beci, Núñez Tomás y Virginia González, con Anguiano y Saborit como suplentes - facultado para declarar la huelga general revolucionaria si las circunstancias

68 "El Luchador", 11-IV-1917.

69 El patriotismo del elemento obrero, editorial del 3-IV-1917.

70 Doble responsabilidad, en "El Tiempo", 2-IV-1917. 
lo exigian o había peligro de una dictadura militar. De otro lado, Saborit y Largo Caballero viajaron a Barcelona para tomar contacto con los líderes sindicalistas, a los que informaron de los contactos que, a su vez, tenían establecidos los socialistas con los republicanos y reformistas. Se tiene poca información sobre estas reuniones y es difícil saber hasta qué punto se llegó a acuerdos concretos, ni sobre la forma de conducir la huelga, ni sobre sus objetivos. Asi las cosas, y coincidiendo con la disolución de la asamblea de parlamentarios en Barcelona, estalló una huelga de ferroviarios y tranviarios, a mediados de julio, en Valencia.

Las noticias que en Alicante da la prensa sobre la situación en estos meses de junio y julio están muy condicionadas por la censura. El 26 de junio habían sido, de nuevo, suspendidas las garantias constitucionales, y la censura previa hacía estragos, ${ }^{71}$ llegando a motivar que el semanario socialista "Trabajo", de Elche, tuviese que suspender su publicación entre el 24 de junio y el 5 de agosto. ${ }^{72}$

Por todo ello nos encontramos mal informados sobre las repercusiones que la huelga ferroviaria de Valencia tuvo en la provincia de Alicante. ${ }^{73}$ La huelga de Valencia acabó transformán-

71 "Si la censura no se suaviza, copiaremos el Padre Nuestro que estás en los cielos o el Almanaque Religioso". ("El Luchador", 28-VI-1917) / "El Día", 7-VII-1917, recordaba los temas que la censura impedia tratar y que no se permitía que apareciesen huecos en blanco en los periódicos / "El Socialistan, 1 y 2-VII-1917, rellena los espacios en blanco con leyendas como éstas: "iObreros! Hablad vosotros en vuestras casas, en vuestros talleres, en todas partes, de todo eso que no permite decir la censura" / "Leed "El Socialista", aunque parezca escrito en otro país distinto del nuestro".

72 Reanudando la labor, en "Trabajo", 5-VIII-1917: la censura tachaba artículos sobre temas nacionales y locales tratados en otros periódicos, copiamos el Padre Nuestro y el Avemaría y se nos prohibió; no se podía dejar huecos en blanco. Ahora salimos, porque se puede dejar huecos en blanco y asi el lector sabrá que ahi se trataba un tema de los que "son motivo de conversación pública y privada de los illicitanos" / "La Libertad" - a buenas en esos momentos con los socialistas - ofrece sus páginas a Vives "por entender que la voz del trabajador no puede dejar de ser oída" (15-VII1917). Vives contesta agradeciendo el gesto y distinguiendo, como era su costumbre, entre unos partidos dinásticos y otros.

73 «El Luchador» 12-VII-1917: «Para lo que está ocurriendo, más valiera que de una vez se suprimiera la prensa, la Constitución, el régimen parlamentario y todas las libertades públicas". 
dose en general y casi enlazó con la huelga general de agosto de 1917. Según algunos historiadores, tal vez en el desarrollo de la huelga ferroviaria hubiese una acción provocadora del Gobierno que, conocedor de los preparativos para la huelga general, la impulsó, apoyando la intransigencia de la Compañía del Norte -que contrastaba con la moderación de los ferroviarios - porque "para sostenerse en el poder, necesitaba una situación de violencia». ${ }^{74}$

Probablemente en relación con la huelga de Valencia, se anunció en Alcoy, por medio de hojas anónimas que incitaban al pueblo y a las tropas a la rebelión, la huelga general para el día 20 de julio: comenzó el paro en el segundo turno, a las seis de la tarde, en las fábricas de Rita Santonja y Modesto Payá, extendiéndose después a casi todas (sólo se trabajó en quince). El día 21 pararon ya todos los obreros del textil, unos diez mil en total. Luego se extendió el paro a los talleres metalúrgicos, a las fábricas de sombreros, cintas, carretes de hilo, género de punto y papel: "Casi toda la población ha secundado el paro". ${ }^{75}$ Para la prensa, no estaban claros los motivos del paro: se hablaba de conseguir la jornada de ocho horas y de instrucciones recibidas de "un delegado forastero". Acudió a Alcoy el teniente coronel de la Guardia Civil, que el 27 daba cuenta al Gobernador Civil de haber alcanzado "un satisfactorio acuerdo". ${ }^{76}$ No hubo incidentes de importancia. ${ }^{77}$

Según el Gobernador Civil de la provincia, Barzanallana, nada anormal ocurrió en el resto de la zona bajo su mando. ${ }^{78}$ La fé-

74 La frase es de Cambó y la recoge Jover en su Historia de España, escrita en colaboración con Ubieto, Reglá y Seco. La tesis de la provocación la lanzó MAXIMIANO GARCIA VENERO y la apoyan otros varios historiadores.

75 "La Correspondencia Alicantina», 21 y 23-VII-1917 / "El Popular», 21-VII1917.

76 "El Tiempo", 27-VII-1917.

77 Según «El Popular», 27-VII-1917, la mayoria de los huelguistas se lo tomó con calma y salió a solazarse al campo: "En los merenderos y sitios permitidos veíanse millones (sic) de personas acampadas con el mayor sosiego riendo y comiendo".

78 Como hemos dicho, Fernanda Romeu, o. c., pág. 138, confunde esta huelga con la de agosto cuando asegura que en julio hubo en Villena y Yecla resistencia a la Guardia Civil y varios heridos y muertos. 
rrea censura de prensa nos impide comprobar la veracidad de su información. ${ }^{79}$ No podemos, pues, situar con total claridad la huelga de Alcoy: pensamos que hay que explicarla en el contexto de la agitación social reinante, en la cual actuarian como desencadenante las noticias llegadas desde Valencia. Sin embargo, no hay por ello que descartar que en ella hubiese también reivindicaciones propias de los obreros alcoyanos, que se utilizarían probablemente para movilizar a los indecisos.

\section{El desarrollo de la huelga de agosto de 1917}

Al producirse la citada huelga ferroviaria, y ante el temor de que provocase reacciones dispersas y desconectadas, se reunió el comité conjunto de la UGT y del PSOE y decidió convocar la huelga general para el día 13 de agosto a las cero horas. Besteiro redactó el documento que llamaba a la huelga y daba instrucciones, explicando al mismo tiempo los objetivos que se perseguían. ${ }^{80}$ Como es sabido, esta huelga tuvo su mayor repercusión en Asturias - donde se prolongó cuando ya había terminado en el resto de España-, Vizcaya, Cataluña, algunas zonas mineras, Zaragoza, Valencia, La Coruña y Madrid, estando en cambio casi totalmente ausente Andalucía y, en general, el campesinado. Pasamos, pues, a reflejar lo sucedido en la provincia de Alicante.

En la capital, el día 13 por la mañana, grupos de obreros de la Casa del Pueblo y del Centro de Sociedades Obreras, es decir, socialistas y sindicalistas, recorren los sitios de trabajo invi-

79 La censura de prensa se utilizaba especialmente contra los periódicos antimonárquicos: "El Luchador", 26-VII-1917, se queja de que no se le autorizan textos ya publicados en otros periódicos: lo cierto es que no da información alguna sobre la huelga de ferroviarios en Alicante. Cuando a finales de julio se levanta la censura, "El Luchador", 1-VIII-1917, publica un artículo de Pablo Iglesias, comenta los sucesos de Valencia, a los que niega todo carácter revolucionario, y recoge el 7-VIII-1917 el Manifiesto de la Federación Nacional de Ferroviarios Españoles, significativamente titulado A los ferroviarios y a la opinión: cómo se provoca un conflicto.

80 El documento, firmado el 12 de agosto por Besteiro, Largo Caballero, Saborit y Anguiano, lo reproduce Gómez LLORENTE, o. c., págs. 305-309. 
tando a la huelga: se declara el paro en el muelle, obras, talleres, imprentas. Los obreros recorren las calles, pero el orden es total. ${ }^{81}$ Las fuerzas de Seguridad - que habían tenido una víspera muy agitada por una corrida de toros benéfica - son concentradas en la madrugada del día 13 al tenerse noticias "de que los trabajadores del muelle pensaban declararse en huelga y que ésta se haría general para los demás oficios, con carácter sedicioso". ${ }^{82}$ No llega el tren correo de Madrid, corren rumores de lo sucedido en el Alto y Medio Vinalopó y se encuentran cortadas las líneas telegráficas y telefónicas. A primeras horas de la tarde continúan los grupos en la calle, los comercios cierran sus puertas, la ciudad tiene el aspecto de los días festivos (están abiertos estancos y cafés), se restablece con la protección de las fuerzas de Seguridad la circulación de tranvías, son custodiadas fábricas y edificios públicos y son detenidos varios obreros, unos por encabezar los grupos que obligaban a cerrar los establecimientos y otros por volcar algún tranvía o significarse entre los huelguistas: entre los detenidos figuran los dirigentes obreros Rafael Millá y Manuel Esquembre, socialista y sindicalista, respectivamente.

A media tarde abandonan el trabajo las operarias de la Fábrica de Tabacos; las líneas férreas a Denia y Murcia funcionan con normalidad, pero no se logra restablecer la comunicación con Madrid, enviándose en automóvil la correspondencia para Villena y pueblos intermedios. Los tipógrafos anuncian su acuerdo de huelga general y no se publica la prensa, con la excepción de "El Tiempo", datista, y "El Día». ${ }^{83}$ Los obreros obser-

81 Resumen de los sucesos últimos, en "Diario de Alicante», 20-VIII-1917/ Según Juan José Castillo, el 8 de agosto envió el ministro de la Gobernación un telegrama circular a los gobernadores civiles con instrucciones muy precisas para reprimir la huelga.

82 El Cuerpo de Seguridad: su actuación con motivo de la huelga, en «El Tiempo", 28-VIII-1917.

83 No salió ningún periódico de la tarde, ese día. Los primeros en reaparecer fueron "El Día" y "El Tiempo". El "Boletín Oficial de la Provincia" no se publicó ni el martes ni el jueves y apareció miércoles y viernes con una sola hoja: todo esto indica la fuerza de la huelga de los tipógrafos. 
van, en general, una "actitud pacífica y expectante». ${ }^{84}$ Tras acordar las autoridades resignar el mando en el Gobernador Militar, sale a las siete de la tarde una sección dél Regimiento de la Princesa que proclama la ley marcial, siendo vitoreados los soldados por un "enorme gentío", al decir de algún periódico. ${ }^{85}$

La proclamación de la ley marcial es publicada en el Boletín Oficial de la Provincia el día 15. Tras aludir a las circunstancias creadas por la huelga de ferroviarios, a las coacciones que se estaban cometiendo en muchos lugares y a los "sucesos ocurridos en esta provincia», y expresar su temor de que "elementos extraños aprovechen la anormalidad creada para producir graves trastornos y alteraciones de orden público», el Gobernador Civil anunciaba que había entregado el mando al Gobernador Militar, Fernando Moltó Ocampo, que lanzó este llamamiento:

Alicantinos: Espero firmemente de vuestra mesura y patriotismo, que en todo momento recordaréis vuestros deberes de ciudadanos, contribuyendo con la serenidad y virtudes cívicas que jamás habéis desmentido, a que se realice mi propósito de restablecer inmediatamente el orden, si llegaran a perturbarlo quienes olvidando sus deberes para con la Patria merecen que se les aplique todo el rigor de la ley.

A las ocho y media de la noche llega el tren correo de Madrid que tenía que haber llegado a las ocho de la mañana, y los viajeros cuentan sobresaltados lo sucedido en Villena y Elda. Por la noche funcionan los teatros normalmente. Las autoridades toman medidas para asegurar el abastecimiento de la ciudad - habia cerrado también el Mercado ese día, aunque al parecer cuando ya casi se habia terminado la venta - y ufuerzas de la Guardia Civil y de Seguridad, con tercerolas, patrullan por

84 "Diario de Alicante", 20-VIII-1917. Un ejemplo curioso de esta actitud lo tenemos en "El Correo", 17-VIII-1917: un grupo de huelguistas acude a la fábrica de yesos "El Cisne", propiedad del director de "El Correo" y político maurista Florentino de Elizaicin, y una comisión pide que cesen los trabajos «en forma correcta, gorra en mano, lo cual demuestra su excelente educación". Pese a las "atinadas observaciones sobre los perjuicios de la huelgan que les hace Elizaicin, se declaran en huelga.

"Diario de Alicante", 20-VIII-1917. 
la ciudad". Esta, según un periódico, parecía "ocupada militarmente".

El martes 14 "transcurrió, dentro de la anormalidad de las circunstancias, con absoluta tranquilidad». ${ }^{86}$ El mercado estaba abastecido y la mayoría de la gente hizo compras para varios días. El alcalde estuvo vigilando que no se produjeran coacciones, impidiendo las fuerzas de Seguridad que fuesen cerradas las puertas del Mercado por algunos grupos. No se trabajó en los muelles ni en las fábricas: el paro fue total. Los comercios permanecen cerrados por la mañana, y a ruegos de la sociedad de Camareros cierran también el Casino y los cafés. Comienzan a circular los tranvías, pero son volcados dos y se ponen piedras en los rieles para paralizar su tráfico. La fuerza pública da varias cargas y practica nuevas detenciones: con todo, los tranvías se retiran aproximadamente a las nueve y media de la mañana. ${ }^{87}$

Según el relato de los hechos que hace meses después «EI Socialista", ${ }^{88}$ la circulación de tranvías excitó a los huelguistas: "La fuerza pública, muy escasa, se vió bastante comprometida, pues las masas de obreros eran enormes, y las cargas que se dieron contra ellos no fueron suficientes para reducirlos». Pese a los carabineros y a las fuerzas del ejército, los huelguistas "más numerosos por momentos y dueños de la situación, destrozaron los tranvías con una facilidad asombrosa".

Hay ofrecimientos del gremio de panaderos al alcalde para elaborar los dueños de tahonas el pan, si fuera necesario. Se publica solamente el diario gubernamental "El Tiempo". La Guardia Civil custodia las centrales eléctricas y patrullan por la población fuerzas del Regimiento de la Princesa. Se practican nuevas detenciones y la Cruz Roja establece diversos retenes. Sigue habiendo problema en las comunicaciones con Madrid, en tanto son normales con Murcia. La tarde fue más tranquila: todo seguía cerrado, hubo algún incidente, siguió la vigilancia de las

"Periódico para todos", 16-VIII-1917.

Según "Périódico para todos". Según "Diario de Alicante», a las diez se suspendió la circulación de carruajes, al ser volcados cuatro tranvías más.

Nuestra jornada. En Alicante, en "El Socialista», 9-XI-1917. 
fuerzas de orden público y los marineros del cañonero "Bonifaz" prestan servicio de vigilancia en los muelles. Funcionan los teatros, trabajan los hornos, protegidos por los soldados, y son detenidos algunos panaderos por ejercer coacciones. Durante todo el día se mantuvieron reunidos el Gobernador Civil y el Militar, el alcalde y el jefe de Telégrafos. ${ }^{89}$

El Gobierno Civil se vio asistido, desde el primer momento, por "el concurso de todos los elementos de orden, sin distinción de ideas políticas", siempre naturalmente dentro de los partidos que aceptaban el sistema. "El Tiempo" elogia mucho las visitas de los políticos liberales alicantinos Alfonso de Rojas y Rafael Beltrán, entonces en la oposición. Para otro periódico, tales ofrecimientos proceden ude entidades y personas de todas las clases sociales para auxiliar su acción en el mantenimiento del orden" .90

El día 15 siguió la huelga, aunque sin afectar ya en nada a la vida de la población: el mercado estaba abastecido, los comercios abiertos, circulaban los tranvías custodiados por soldados, que ocupaban "las bocacalles céntricas". Comienzan a llegar a Alicante presos procedentes de toda la provincia, y se siguen practicando detenciones en la capital. Las líneas férreas de Denia y Murcia siguen funcionando con normalidad, y la de Madrid con retrasos y precauciones. ${ }^{91}$

El 16 sigue la situación en forma semejante al día anterior: las tropas ocupan la ciudad, custodian los tranvias, los comercios están abiertos, pero "sigue la huelga. No se trabaja en los muelles, fábricas ni talleres. En las calles se ven grupos en actitud pacífica y expectante». Funciona con normalidad ya el ferrocarril de Madrid, llegan más detenidos de la provincia y siguen las detenciones en Alicante. Hay un intento de que se suspenda el trabajo en la Fábrica de Tabacos, pero los soldados disuelven el grupo que lo pretendía. Se empieza a trabajar en los muelles, con el personal de a bordo y algún esquirol, protegidos fuertemente por las tropas. Por la noche y para acentuar la imagen de

"Periódico para todos", 16-VIII-1917 / "Diario de Alicante", 20-VIII-1917.

91 "Diario de Alicante", 20-VIII-1917. 
normalidad, la Banda de música del Regimiento de la Princesa da un concierto en la Explanada. ${ }^{92}$

El 17 se reanuda el trabajo en más fábricas y talleres; en el puerto trabajan ya algunos asociados ("el puerto está vigiladísimon) y circulan algunos tranvías ya sin la protección de la Guardia Civil. "Es completa la tranquilidad, pero siguen las precauciones". Seguían llegando a la capital los detenidos de la provincia y la autoridad militar había empezado a incoar expedientes. Según "La Correspondencia Alicantina", los que habían cedido en el puerto eran los afiliados a "La Terrestre" - unos cincuenta de ellos - mientras que otros y los de "La Marítima" mantenían huelga aún. Anunciaba también este diario que esa misma tarde entrarían ya a trabajar los albañiles, y daba crédito a un rumor según el cual habian comenzado las represalias en la Fábrica de Sacos. A mediodia se retira la vigilancia militar de las líneas férreas, ante la normalidad reinante. ${ }^{93}$ Seguían sin salir algunos periódicos, como "La Vanguardia", "El Luchador" y "Diario de Alicante", mientras que los más cercanos al sistema habian reanudado su publicación.

El 18 se daba prácticamente por terminada la huelga: aumentaba el número de obreros que se reintegraban al trabajo, aunque muchos obreros de la comarca alicantina - Villafranqueza, San Juan, Muchamiel - no habian acudido a trabajar por miedo a las coacciones. Otros periódicos hablaban de total normalidad: se trabajaba en "Fourcade y Provot", en "Las Palmas" - aunque aquí se había tenido que suspender el trabajo por falta de material-, en "La Unión Española" y en la "Cros". ${ }^{94}$ El lunes 20 la situación era totalmente normal y la

Ibídem / Según otros periódicos ("La Correspondencia Alicantina", "Periódico para todos") a lo largo del día ya se volvió al trabajo en algunos talleres, disminuyendo los piquetes y las coacciones de los obreros. En el mueIle, algunos pasajeros que se dirigen a Barcelona y a Francia, ganando a cambio el pasaje - serian campesinos que emigraban-, trabajan en la carga y descarga de los buques para que no se retrase su salida / "El Día", 16-VIII-1917.

93 "La Correspondencia Alicantina», "El Popular» y "El Día», 17-VIII-1917 I "Diario de Alicante", 20-VIII-1917 / Según "El Socialista", 9-XI-1917, desde el dia 15 al 17, en que se volvió al trabajo, hubo tranquilidad.

94 "El Correo" y "El Día», 18-V.III-1917 / "La Correspondencia Alicantina» 18VIII-1917. 
prensa - aparecían ya todos los órganos de opinión-comienza su reflexión y comentarios sobre los hechos, que veremos más adelante. Al propio tiempo, comienzan los juicios militares contra los implicados.

En Alcoy el paro empezó el día 13 a las ocho de la tarde, y el dia 14 por la mañana comisiones de obreros marcharon por las fábricas y consiguieron una total adhesión a la huelga, así como el cierre de los comercios. A las cinco y media de la tarde, el coronel Fernández, del Regimiento de Vizcaya, proclama la ley marcial ante un grupo bastante numeroso de obreros, unos tres mil, que vitoreaban al ejército, en tanto gritaban contra la Guardia Civil a caballo que acompaña a la compañía del Regimiento de Vizcaya. Los guardias civiles cargaron, hubo disparos y carreras, sin que se produjeran desgracias personales. La ciudad fue tomada entonces militarmente y se vigilaba la entrada y salida de sus casas de los socialistas y sindicalistas más conocidos. ${ }^{95}$ Parece, sin embargo, que a pesar de este incidente, la actitud general de los obreros fue pacífica. El miércoles 15 abrieron los comercios ya, pero siguieron en huelga casi veinticinco mil obreros. Comienzan las detenciones, ${ }^{96}$, pero la huelga seguía con bastante fuerza, si bien en actitud pacífica: la prensa alcoyana aconsejaba la vuelta al trabajo ${ }^{97}$ y aludia a la defección, antes del 13 de agosto, de caracterizados republicanos, que habian abandonado Alcoy apresuradamente. ${ }^{98}$

"El Socialista", 18-XI-1917 / En cambio, la información de "La Correspondencia Alicantina", 19-VIII-1917, sobre lo sucedido en Alcoy era considerada calumniosa por los obreros, a los que se acusa de gritar "como pieles rojas". Según "La Correspondencia Alicantina», "aqui terminó la epopeya revolucionaria». "Han sido detenidos y encarcelados los principales causantes de la agitación" ("La Correspondencia Alicantina", 20-VIII-1917) / "El Luchador", 20VIII-1917, cita concretamente a Corbi / Según "EI Socialista", 18-XI-1917, el dia 15 son detenidos Jorge Gisbert Payá, Montaner y varios sindicalistas, y es buscado el socialista Rafael Laliga, que es capturado poco después.

97 "El Liberal», 18-VIII-1917 / La Huelga general de Alcoy, en "La Lealtad", 23VIII-1917.

98 "Hacer el capitán Araña se llama esta figura». Más adelante, ("El Liberal», 8-IX-1917) asegura que cuando fue clausurada la Casa del Pueblo, el jefe datista alcoyano Francisco Moltó conferenció con el subjefe radical Enrique Romeu y salieron de Alcoy "los elementos de izquierda a quienes se atribuye la dirección de la huelga". 
La huelga se mantuvo en forma casi unánime hasta la tarde del día 21, martes: esa tarde, una hoja clandestina (que "El Liberal" atribuye a los datistas) convoca a los obreros a regresar al trabajo al día siguiente, cosa que hacen en forma casi absoluta. La ciudad recobra su aspecto habitual, se suprimen centinelas y patrullas callejeras, etc. Los centros obreros -desde los anarquistas hasta la radical Casa del Pueblo- estaban clausurados. Sin embargo, según "El Socialista", el pueblo no obedeció las incitaciones de las autoridades, sino que "esperó órdenes de la conciencia popular", reintegrándose al trabajo el día 23 , tras haber sido puestos en libertad todos los detenidos, excepto Laliga y Gisbert.

En Elche, hemos de señalar la curiosa ausencia de toda referencia a la problemática nacional en los últimos números de "Trabajo" publicados antes de la huelga: de la lectura de los números del 5 y 12 de agosto nada hace suponer que se está en vísperas de tan importantes acontecimientos, pues la atención del semanario socialista está atraída por pequeños problemas locales. Los obreros fueron al paro en su mayoría, pero el comercio no llegó a cerrar en ningún momento. El dia 15 se producen cinco detenciones, entre ellas las de Matilde Hernández y Juan Barceló, que «según parece, estaban en comunicación con el comité de Madrid". ${ }^{99}$ Además de los citados, fueron detenidos otros socialistas (Antonio Cañizares), varias mujeres (Palmira y Libertad Galiano Asencio, Josefa Martínez Lloréns, Adriana Amorós Alarcón) y varios anarquistas (por ejemplo, los hermanos Francisco y José Navarro González); en total, quince personas. ${ }^{100}$ En general, la situación fue muy pacífica en Elche y ni siquiera llegaron a suspenderse las tradicionales fiestas de agosto. ${ }^{101}$ La prensa elogia a obreros y autoridades por su cordura y prudencia, lo que a su vez explicaría el escaso número de deten-

99 "Diario de Alicante", 20-VIII-1917.

100 "Trabajo", 21-X-1917.

101 "La Libertad", 26-VIII-1917 / Según "El Día», 18-VIII-1917, la huelga en Elche no tuvo gran importancia "al coincidir con las fiestas de agosto". 
ciones. ${ }^{102}$ En el Ayuntamiento se produce la esperable adhesión al partido en el Gobierno de liberales, tradicionalistas e independientes upara el caso de que algunos perturbadores lograsen alterar el orden". ${ }^{103}$ Se constituyó en Elche una especie de guardia -cuya relación publica "Trabajo" el 21 de octubre y entre los cuales hay muchos patronos - "a cuyas manos se confió el orden, la paz y la moralidad de Elche durante el período de la huelga y de suspensión de garantías constitucionales". Según el semanario socialista "Trabajo", la huelga fue aprovechada por los conservadores para atacar a los socialistas ${ }^{104}$ y por algunos patronos para hacer caso omiso de la tarifa en la industria alpargatera "pagando una y más clases por debajo del precio consignado en tarifa». ${ }^{105}$.

La huelga duró en Elche al menos hasta el día 20 y las autoridades, pese al carácter pacífico de ella, tomaron sus precauciones, y fuerzas del ejército y de la Guardia Civil custodiaban la estación del ferrocarril.

En Crevillente el paro «alcanzó mayor unanimidad y empuje que en Elche y... el comercio cerró sus puestos». ${ }^{106}$ No tenemos noticias del desarrollo del paro, pero debió ser totalmente pacífico pues no hubo detenidos.

La mayor virulencia la alcanzó la huelga de agosto en la comarca del Alto Vinalopó y en Elda. En Villena tenía "gran arraigo el socialismo y... una organización perfecta y robusta. Una prueba de las fuerzas de los socialistas en esta ciudad eś su repre-

"La Libertad", 2-IX-1917: los obreros organizados, en los que tenian gran influjo los socialistas, "se han conducido esta vez, como siempre, con acierto y prudencia». Elogia la sensatez de sus dirigentes / Una visión distinta, en el conservador "La Lealtad", 26-VIII (España ha pasado por trances dificilísimos), 30-IX ( Renació la calma!), 7-X (Confiamos en nuestro ejército) y 14-X-1917 (La prosperidad de España).

103 Sesión del Ayuntamiento de 17-VIII-1917.

104 Véanse los artículos del semanario "La Lealtad", idóneo, de 26-VIII y 2-IX1917, con furibundos ataques a Vives: los obreros, hartos de manejo, se dan de baja en el Círculo Obrero; los idóneos esperan, y desean que "Trabajon no se vuelva a publicar, etc.

105 "Trabajo", 21-X-1917.

106 Ibídem / “El Día», 17-VIII-1917: en Crevillente, huelga de obreros de las fábricas de harinas y esteras. 
sentación en el Ayuntamiento, donde tienen varios concejales, entre ellos los primeros tenientes de alcalde". En la madrugada del lunes 13 de agosto, a las dos y media, salieron los obreros del Centro Socialista, encabezados al parecer por concejales y tenientes de alcalde, con el propósito de aislar la ciudad. A unos 4 kilómetros de Villena, arrancaron los raíles y cortaron los hilos de telégrafos y teléfonos, en la línea de Alicante a Madrid; posteriormente hacen algo semejante en las líneas férreas de Villena a Jumilla y de Villena a Muro. Se distribuyen por grupos en los accesos a la ciudad, no permitiendo la entrada o salida a nadie. Según las noticias oficiales, una casualidad impidió el descarrilamiento del tren correo procedente de Madrid: tras ser recompuesta la vía, el tren llegó a la estación de Villena. Entre tanto, y siempre según la información oficial, un grupo de mujeres y chiquillos walarmaron al pueblo profiriendo gritos subversivos". La fuerza allí presente, cinco guardias civiles y un teniente, no podían contenerlos y los huelguistas fueron durante casi todo el día 13 dueños de la ciudad, no permitiendo el paso de ningún ferrocarril, pese a estar ya reparadas las líneas.

A media tarde se presentaron seis parejas de la Guardia Civil, procedentes de Monóvar: son recibidas con insultos y denuestos: "las fuerzas, con buen sentido de su jefe, optaron por la pasividad, pues apelar a la violencia contra los revoltosos, hubiera constituido una temeridad". A las cuatro y media llega un tren de Alicante, con fuerzas de la Guardia Civil al mando de un teniente coronel y consiguieron despejar la estación uhuyendo los revoltosos doloridos de los culatazos de la guardia civil». Los trenes pueden seguir su marcha y así el correo de Madrid llega a Alicante hacia las ocho de la tarde, haciendo sus viajeros sobresaltada narración de estos hechos. La Guardia Civil captura a dos muchachos y los "revoltosos" acuden al alcalde para que interceda para su liberación, cosa que éste hace oralmente y por escrito, pero la Guardia Civil se niega: "Los revoltosos se hallaban dispuestos a realizar toda clase de violencias para que los presos fueran libertados". Se cortan los cables de la luz y la noche transcurre sin ella, recorriendo varios grupos las calles en "actitud subversiva". Durante el día 13 ni las fábri- 
cas ni el comercio abrieron sus puertas. ${ }^{107} \mathrm{Al}$ anochecer, salen de Alicante hacia Villena fuerzas del Regimiento de la Princesa y desde Valencia fuerzas del Regimiento de Guadalajara: se trataba, pues, del foco que las autoridades consideraban más peligroso en toda la provincia.

Los sucesos más graves se produjeron en la madrugada del día 14: sobre las tres y media, los grupos de huelguistas atacan a pedradas y a tiros - según la información oficial-y la Guardia Civil que custodia la estación dispara, casi a ciegas: "Solamente se veían los fogonazos de los disparos, y de este modo largo rato hasta que cada guardia disparó los proyectiles de tres peines". En el incidente muere el joven Martín Hernández, "hijo de una familia acomodada, que venía en el tren y quiso huir saltando la valla de la estación", y resultaron heridos numerosos paisanos, que intentaban - de nuevo, según la información oficial - rescatar a los presos: "La represión fue dura", siendo muchos los heridos curados ocultamente en sus casas. La llegada de las tropas procedentes de Alicante y Valencia permitió a las autoridades dominar completamente la situación y dieron comienzo las detenciones: entre otros - unos veinte- los tenientes de alcalde Luis Bellod Galbis, Antonio López Fernández y Calixto Díaz Navarro, así como el "caracterizado republicano Agustín Michavila", otros socialistas y varias mujeres. ${ }^{108}$ Martín Hernández fue la única víctima mortal de la huelga general en la provincia de Alicante y, según todos los indicios, se trató de un accidente: en Yecla - donde acudieron también las tropas procedentes de la Capitania General de Valencia - hubo, en cambio, tres muertos y varios heridos. ${ }^{109}$

107 Básicamente, esta información - de origen oficial- procede de "El Día", 18-VIII-1917, "La Correspondencia Alicantina" y "Diario de Alicante", 20VIII-1917.

108 Cöinciden las informaciones de "Diario de Alicanten, 21-VIII-1917, y "La Correspondencia Alicantina", 20-VIII-1917, diarios muy distantes ideológicamente, lo que abona nuestra creencia en el origen oficial de la información. Sobre la actitud del ejército, resultan muy ilustrativas unas declaraciones que publica "El Día», 16-VIII-1917, del Capitán General de Valencia, general Tovar: "He confiado el mando de los 500 hombres que hay en Sax y Villena al coronel señor Montero, a quién envié el lacónico telegrama siguiente: Déme cuenta de las armas recogidas y hombres detenidos". 
En Sax -el informe oficial habla también de que allí tiene "hondas raices el socialismo", pero creemos poder contradecir este aserto e indicar un mayor predominio, por el influjo de la vecina población de Elda, del anarcosindicalismo- también fueron cortadas las comunicaciones telegráficas y telefónicas, así como la línea férrea. Además, los huelguistas se dirigieron al Ayuntamiento, donde rompieron muebles y retratos, y destruyeron el Archivo Municipal y el del Juzgado, en especial utodo el material impreso del recaudador de contribuciones". ${ }^{110}$ Esta actuación - de la que no conocemos otro ejemplo- indica, de un lado, el secular odio a las contribuciones y, probablemente, ese carácter anarcosindicalista de que hablábamos. Al intentar impedir el paso del tren que transportaba las tropas desde Alicante, fracasan los sublevados y la fuerza pública restablece el orden sin demasiadas dificultades. Los detenidos son enviados pronto a Alicante. ${ }^{111}$

En Eldä-según el informe oficial «no es en este pueblo menos fecundo el socialismon, cosa bastante incierta: predominaba el anarcosindicalismo también-se paralizó el día 13 el trabajo en todas las fábricas y cerraron los comercios. Un grupo numeroso se dirige a la estación y los empleados ferroviarios se asustan: los huelguistas les tranquilizan, pues nada va contra ellos: sólo pretenden impedir las comunicaciones. "Los jefes del movimiento hicieron saber a las masas que podian retirarse hasta el día siguiente en que secundando el movimiento de la capital, se proclamaría la república, y se tomaría posesión del mando de la ciudad constituyéndose el Ayuntamiento y nombrándose nuevo alcalde. Al día siguiente les sorprendió la fuerza de infanteria, que impidió todo movimiento y restableció la tranquilidad”. ${ }^{112}$ El desarrollo de los hechos en Elda nos ilustra bien

110 El Ayuntamiento, en sesión del 7-V-1918, consulta al Gobierno Civil sobre "la norma que debe seguir el Ayuntamiento en la reconstrucción de libros y papeles que fueron quemados en los sucesos del 14 de agosto últimon. La consulta se reproduce en las sesiones del 2-VII y 11-VIII-1918.

111 "La Correspondencia Alicantina" y "La Unión Democrática", 21-VIII-1917. Se trata de una información "casi autorizada".

112 "La Correspondencia Alicantina", 20-VIII-1917 / "La Unión Democrática", 21-VIII-1917. 
sobre el carácter de la huelga: tras unas primeras medidas, los huelguistas se mantienen a la espera de los acontecimientos y, desde luego, no parecen en absoluto estar coordinados con los de poblaciones cercanas.

En el Vịnalopó Medio también tuvo la huelga de agosto bastante importancia. En Novelda sí que habia un claro predominio socialista: el día 14 la directiva de la Sociedad Obrera "La Emancipación" lanzó la huelga, que siguieron unos ochocientos obreros en forma totalmente pacífica. Por la tarde, se proclama la ley marcial y comienzan las detenciones de los más caracterizados dirigentes de "La Emancipación". Según la prensa republicana, ${ }^{113}$ algunos muchachos al margen de los huelguistas cortaron los hilos del telégrafo y la vía férrea: había llegado antes de estos sucesos el bando que declaraba el estado de guerra, pero se tardó en publicarlo casi ocho horas, por lo que "lo de la Estación pudo haberse evitado". "El Luchador" desmiente algunas informaciones aparecidas al socaire de la huelga, en especial que los sucesos fuesen graves, que se hiciera desacato alguno a la autoridad y, sobre todo, que se efectuasen disparos por parte de los huelguistas a la llegada de las tropas.

Finalmente, en Aspe también se produjo la huelga de agosto de 1917 y fueron detenidos, y encarcelados hasta noviembre en el castillo de Santa Bárbara de Alicante, al menos cuatro ciudadanos de aquella localidad. ${ }^{114}$

Las comarcas del Alto y Medio Vinalopó estuvieron vigiladas por las tropas procedentes de Valencia y Alicante hasta bastantes dias después de los sucesos; concretamente, cuando las tropas, a primeros de septiembre, regresaron a sus cuarteles desde los demás pueblos de la zona, algún contingente permaneció en Sax.

Lógicamente, los Ayuntamientos, entidades patronales y demás "fuerzas vivas" adoptaron una actitud de total apoyo al Gobierno, ante los acontecimientos: la prensa publicó numerosos artículos elogiosos para las fuerzas de Seguridad, autorida-

113 "El Luchador», 27-X-1917 y 6-VI-1918/ "Diario de Alicante», 20-VIII-1917.

114 "La Emancipación", de Novelda, también tenía afiliados en Aspe, donde había predominio socialista. 
des, telegrafistas, etc.; diversas corporaciones municipales hicieron constar en acta su adhesión al Gobierno y su gratitud a las autoridades militares; ${ }^{115}$ y algo semejante realizaron la Cámara de Comercio de Alicante, ${ }^{116}$ las "personas más distinguidas de Villena" - que ofrecieron un banquete a la oficialidad ${ }^{117}$ - y varios industriales de Elda que, además, aprovecharon la ocasión para solicitar que fuese aumentada la guarnición de Guardia Civil allí existente. ${ }^{118}$

\section{LA REPRESION DE LA HUELGA DE 1917}

La represión del movimiento huelguístico comenzó el mismo día 13. Los detenidos fueron los miembros dirigentes de las sociedades obreras y aquellos que se habian distinguido en algún acto violento. Al mismo tiempo, eran clausurados los centros y sociedades obreras. En Alcoy el día 24 de agosto permanecían todavía cerradas la Casa del Pueblo y la Federación del Arte Textil, así como los locales de la Agrupación Socialista y el Ateneo Sindicalista. Se levanta la clausura el dia 25 y permanecen en la cárcel solamente dos obreros: se hacen colectas para ayudarles. La represión en Alcoy fue la más benigna de todos los lugares de la provincia, hecho curioso, pues si no se produjeron incidentes semejantes a los de Villena y Sax, la huelga fue bastante importante: ¿se trataría, tal vez, de cierto temor a una clase obrera firmemente organizada y con larga experiencia de lucha? ${ }^{119}$

115 Por ejemplo, los ayuntamientos de Alicante, Villena, Elche y Hondón de las Nieves. El de Elda, en la sesión del 21-VIII-1917, acordaba también que se diese una comida extraordinaria a la tropa, a costa del Ayuntamiento, y se nombrase una comisión para homenajear a jefes y oficiales. Pero, al propio tiempo, abrían suscripción para los familiares de los presos y pedían que "sin desdoro ni menoscabo de la recta justicia, haya piedad para todos los obreros encarcelados con motivo de dichos sucesos".

116 "Diario de Alicante» y "La Unión Democrática», 21-VIII-1917.

117 "El Tiempo", 23-VIII-1917.

118 "Diario de Alicante", 6-IX-1917.

119 "El Luchador", 26-VIII-1917/ Para la represión a nivel nacional, hay datos en el libro Los sucesos de agosto en el Parlamento, que recoge los discursos de Largo Caballero, Anguiano, Saborit, Besteiro, Marcelino Domingo y Eduardo Barriobero. 
En Elche, como hemos dicho, hubo unos quince detenidos: cuatro de ellos permanecían todavía en la cárcel de Elche a mediados de octubre, mientras que los dirigentes ugetistas Barceló y Cañizares se encontraban presos en el castillo de Alicante. ${ }^{120}$

Ignoramos absolutamente las causas que llevaron a la detención en Jávea y posterior encierro en el castillo de Alicante del ex-diputado provincial Romualdo Catalá y los señores Albí, padre e hijo. ${ }^{121}$

En relación con los detenidos en Alicante, el mismo 20 de agosto se constituyó el tribunal para juzgar a tres de los detenidos el día 13 por coacciones: Rafael Millá, presidente entonces de la Sociedad Tipográfica, y Manuel Esquembre son condenados a cuatro meses y un día de arresto ${ }^{122}$ y Juan Baño, acusado de llevar una gran navaja con la que obligaba a los comerciantes de la calle Mayor a cerrar, a multas de 125 y 25 pesetas: «El Luchador" lamentaba esta condena de unos obreros "tan queridos de todos por su honradez y laboriosidad". ${ }^{123}$

Las detenciones más numerosas se produjeron en las comarcas del Medio y Alto Vinalopó. En Villena, Sax, Elda y Novelda fueron detenidas, en los primeros días, unas setenta y cinco personas. Posteriormente, y como consecuencia de las declaraciones de los detenidos, lo fueron otras. Así, en Novelda, fueron detenidas en un primer momento veintitrés personas, entre ellas el industrial y republicano Daniel Valero («supuesto instigador de la rebelión»), el director del semanario "Avante" - de inspira-

"Trabajo", 21-X-1917. La mayoría fue pronto puesta en libertad: «... ha resplandecido la clemencia y misericordia dentro de la más estricta justicia, en pro de los encarcelados con motivo de las coacciones habidas en esta población, durante los últimos sucesos revoltosos, habiendo sido por consiguiente puestos en libertad". ("La Lealtad", 2-IX-1917).

"El Luchador", 22-VIII-1917 / Según "La Correspondencia Alicantina", 20VIII-1917, eran tres reformistas, muy amigos de Melquiades Alvarez: Romualdo Catalá Guarner, su padre Juan Bautista Catalá Gavilán y José Albi Romaní / Fueron puestos en libertad provisional el 26-VIII-1917. Creemos que esta detención se debió a luchas caciquiles a nivel local.

Ambos serán puestos en libertad provisional el 15 de septiembre.

"El Luchador", 21-VIII-1917. 
ción republicana - Lorenzo Fenoll y los presidentes y secretarios de las sociedades de albañiles, canteros y alpargateros. ${ }^{124}$ En Sax, los detenidos permanecieron en prisión, algunos, hasta la amnistía general de mayo de 1918; en cuanto a la Sociedad Obrera, permaneció clausurada hasta enero de 1918 "con gran contento de los villanos caciques". ${ }^{125}$

En Villena fueron detenidas, en un primer momento, más de veinticinco personas y el día 22 de agosto el juez instructor militar daba un plazo de quince días para presentarse ante su autoridad a José Maruenda Santana «de profesión Maestro de Instrucción Primaria y concejal socialista", "por haber capitaneado uno de los grupos revoltosos durante los disturbios de los días 13 y 14 últimos". ${ }^{26}$ Maruenda será detenido el 6 de septiembre, por la Guardia Civil, en las cercanías de Castalla, cuando se dirigía a Alicante para entregarse. ${ }^{127}$ El Centro Obrero permaneció también clausurado hasta primeros de 1918. De otro lado, cuando se levantó la censura de prensa, se pudo conocer algún nuevo dato de la represión: así, la información según la cual el teniente de la Guardia Civil hace leer el bando declarando el estado de guerra a unos afiliados a la Juventud Socialista y les advierte acto seguido de que uen cuanto los viera reunidos, los disolvía a balazos". ${ }^{128}$

El 4 de septiembre regresan a Valencia dos compañías del Regimiento de Guadalajara, que se encontraban en Villena y La Encina, permaneciendo todavía otras dos en Sax y Yecla. El día 4 de octubre quedaban solamente en la cárcel del castillo de Alicante quince de las mujeres detenidas. ${ }^{129}$ Las autoridades mili-

124 "El Luchador", 27-X-1917, protestaba por ello, pues en los registros efectuados en los domicilios de estos obreros nada comprometedor, ni siquiera proclamas, se había encontrado: eran perseguidos por sus ideas y acosados por hambre.

125 "El Luchador", 13-XII-1917.

126 «El Luchador», 22-VIII-1917.

127 "Diario de Alicante", 7-IX-1917.

128 "Diario de Alicante", 8-XI-1917.

129 La participación femenina en la huelga fue importante, sobre todo en Elda y en el Alto Vinalopó: según "Diario de Alicante», 20-VIII-1917, de las detenidas, una tenía 18 años y dos, 60; "Parece que se les acusa de excitar los ánimos de los huelguistas de dichos pueblos, llevando banderas al frente de las masas". 
tares seguían, a primeros de octubre, interesando la captura de otras personas, acusadas de haber "capitaneado grupos revolucionarios". Y el 8 de octubre anunciaba el Gobernador Militar la puesta en libertad de veintiún presos de Callosa "comprendidos en uno de los sumarios incoados por los recientes sucesos": es la única noticia que tenemos de que la huelga de agosto se hubiese producido también en Callosa del Segura. ${ }^{130}$

A finales de octubre se informa que de los 140 que fueron detenidos a lo largo de la huelga y días siguientes, permanecían todavía encarcelados 97 - procedentes de Villena, Sax, La Cañada, Benejama, Novelda, Aspe, Elche y Alicante-, algunos de los cuales no estaban acusados de nada. Todavía el 31 de octubre fueron detenidos 14 obreros en el Alto Vinalopó: en total eran 108 los presos. En noviembre se aceleró la vista de las causas y fueron libertados en pocos días más de 50 presos, tras la llegada del general Tovar, Capitán General de la Región. ${ }^{131}$ Pero todavía quedaban en el castillo unos 30 presos, doce de ellos de Villena, cuya libertad piden varios Ayuntamientos de la provincia - los de Crevillente, Alicante, Torrevieja y Elche- que se pronuncian por la amnistía.

Hacia Navidad de 1917 salieron algunos presos más del castillo, cinco de Sax y dos de Villena. El día 28 se celebra un consejo de guerra contra Francisco Martín Arrimada, cornetín de la Banda Municipal y único preso de Alicante que quedaba encarcelado y que fue absuelto, pero el Gobernador Militar recurrió y este recurso mantendría a Martín Arrimada en prisión hasta mayo de 1918. ${ }^{132}$ En enero fueron libertados siete presos más, tras una gestión de Pablo Iglesias ante el Gobierno. ${ }^{133}$

130 "Periódico para todos", 8-X-1917. (No creemos que la información se refiera a Callosa de Ensarriá.)

131 "El Socialista", 18-XI-1917, informa de que han sido puestos en libertad 8 mujeres y 59 hombres -20 de Villena, 18 de Cañada, 8 de Elda, 7 de Sax, 4 de Aspe y 2 de Benejama.

132 "El Dia", 28 y 29-XII-1917. Martínez fue sorprendido con impresos y pruebas comprometedoras en una visita a los presos del Castillo, por lo que es acusado de "inducción a la rebelión» / "El Luchador", 29-XII-1917 y 13-V-1918/ "El Socialista", 30-XII-1917.

"El Socialista", 20-I-1918/ «El Día», 26-I-1918. 
Los últimos presos de agosto de 1917 saldrían en mayo de 1918 , con la aplicación de la amnistía tras las elecciones legislativas y la subida de Maura al poder: tras permanecer nueve meses en prisión, salieron José Maruenda Santana - maestro y segundo teniente de alcalde de Villena-, Antonio López Hernández y Calixto Díaz Navarro - igualmente tenientes de alcalde de Villena-, Sebastián Sáez Ibáñez - de esta citada población, al que "Diario de Alicante" califica de "segundo jefe del movimiento revolucionarion (el primero era, por supuesto, Maruenda)-, José Jorge Llorca - conserje de la Casa del Pueblo de Villena-, y los también habitantes de dicha ciudad Andrés Navarro Navarro, Francisco González Tomás, Juan Lillo Santiago, ${ }^{134}$ Manuel Muñoz Navarro y Manuel Cañizares López. Y dos ciudadanos de Sax: Juan José Gil Ochoa y Antonio Sánchez Esteve. ${ }^{135}$ Posteriormente, se consiguió la aplicación de la amnistía al citado Francisco Martín Arrimada y a Ginés de Alberola. ${ }^{136}$

\section{Carácter de la huelga general de 1917}

Sobre el carácter de la huelga general de agosto de 1917 y las causas de su fracaso se ha discutido mucho entre los historiadores, y también hubo discrepancias y opiniones para todos los gustos en la época misma, entre los propios protagonistas de los hechos. Así, para J. A. Lacomba, "en 1917 sobrevenía, también, la primera irrupción del proletariado en la historia de España, con clara conciencia de su acción. El obrero habia adquirido ya una conciencia de su situación, y buscaba su redención a través de un movimiento revolucionario total». La huelga, según el mismo autor, fue emprendida de muy distinta forma por la CNT y por la UGT, entre las que faltó conexión; el papel protagonista correspondió a la UGT que proclamó un concepto de "huelga pacífica", en tanto que la CNT habria pensado, de

134 Según "Diario de Alicante", 13-V-1918 / Según otros periódicos, se trataba de Victoriano Navarro.

135 Todos estos «honrados ciudadanos" aparecen fotografiados en «El Luchador", 22-V-1918.

136 Ambos fueron dééndidos por el capitán Hernández Mira, que gozaba de grandes simpatías entre los obreros. 
acuerdo con sus convicciones, una "huelga violenta, total, plenamente revolucionaria y presta a ser todo lo radical que necesario fuese", pues pensaba sobrepasar el marco de los acuerdos con la UGT. ${ }^{137}$ Lacomba resume así las causas del fracaso de la huelga:

Básicamente, porque aún no estaba preparada, porque el ejército se le enfrentó y porque la burguesía y los partidos republicanos se desentendieron de ella; junto a esto, el proletariado actuó desunido y el campesinado no participó en el movimiento... La revolución de 1917 pudo haber sido otra cosa $-y$ alcanzar distinto resultado- si hubiera habido en los sectores revolucionarios una idea más clara de la crisis y menos precipitación; si las clases medias y los capitalistas hubieran tenido más valor, y si hubiera existido una figura de altura nacional, capaz de recoger aquél sentimiento patriótico y transformarlo en una corriente dinámica con contenido claro.

Para Casimir Martí, ${ }^{138}$ las causas del fracaso -en las que, según él, coinciden todos los historiadores prácticamentefueron: en primer lugar, la infundada confianza que pusieron las centrales sindicales en el papel que en la revolución proyectada iban a desempeñar los sectores burgueses: de ahí, la colaboración en Cataluña entre cenetistas y los republicanos de Marcelino Domingo, y en el resto del Estado, entre los socialistas y los reformistas y republicanos. En segundo lugar, el hecho de que el ejército no se encontrase en la situación crítica en que se vería tras el desastre de 1921 en Marruecos, lo que hizo funcionar "sin dificultad los reflejos espontáneos que le inclinaban al mantenimiento del orden y la unidad nacional y a la apatía hacia el sindi-

137 J. A. Lacomba, O. c: / A. Pestaña, Lo que aprendí en la vida; "Se volcaron las cajas de fondos de los sindicatos entregando hasta el último céntimo para comprar pistolas y fabricar bombas".

138 Casimir Marti, Panorama de los estudios monográficos sobre el movimiento obrero español del 1900 a 1936, en FERnANDo ToRRES (ed.), Historia y práctica del movimiento obrero en España, Valencia, 1977. 
calismo anarquista". ${ }^{139} \mathrm{Y}$ en tercer lugar, la falta de sincronización entre la clase obrera agrícola y la industrial.

En relación con el carácter de la huelga, hay discrepancia entre los distintos historiadores. Para los proclives al anarcosindicalismo, el fracaso de la huelga reafirmó a los cenetistas "en sus convicciones de que el camino político no era el que convenía a los intereses obreros y esta actitud marcó un distanciamiento respecto el socialismo y más pronunciado aún en relación con el republicanismo catalanista». ${ }^{140}$ Y llegan a más, ${ }^{141} \mathrm{a}$ asegurar que el único fin de la huelga era "entregar a la patronal ferroviaria, atados de pies y manos, a los obreros cuyas acciones habian escapado por un instante a su control (el de los dirigentes socialdemócratas)", por lo que consiguieron estos "burócratas sindicales algunos mandatos en el Parlamenton. ${ }^{142}$

139 Según Stanley G. PAYNe, Los militares y la política en la España contemporánea, "la violencia del ejército contra los huelguistas fue una regla aplicada en toda España", porque "el establecimiento de la ley marcial proporcionó al ejército un enemigo en quien concretar su resentimiento y pronto, oficiales y tropas a la vez, reaccionaron con brutalidad contra los huelguistas" / RAmón Pérez de AyAla, La crisis política de 1917. Los últimos sucesos, recoge unas declaraciones de un jefe militar - "Lo que hace falta es duplicar el contingente del Ejército, y menos fabriquitas y menos obreritos, que para nada sirven, si no es para dar qué hacer" - y del Capitán General de Madrid - "La vida de un obrero vale 0,15 pesetas, que es lo que cuesía un cartuchon- verdaderamente espeluznantes / A nivel provincial, la actitud del ejército y de las fuerzas de orden público ante la huelga fue tan monolítica como en el resto de España, con una excepción, que no está demasiado clara: la separación de dos miembros del Cuerpo de Seguridad de Alicante "por su actuación durante la pasada huelga: ambos guardias eran muy queridos por su conducta irreprochable". ("Diario de Alicante", 31-VIII1917).

140 J. Gómez CASAS, Historia del anarcosindicalismo español, Zyx, Madrid, 1969. Lo que no impide que, a veces, reclamen la gloria del movimiento: "A la hora de la verdad, apenas si acudió alguno que no fuese cenetistan. (Joan Ferrer, en La revuelta permanente.)

141 V. DE POL, Ascaso, Durruti, Jover. Su obra de militantes. Su vida de perseguidos, recogido por HANS MAGnus ENZENSBERGER, El corto verano de la anarquía. Vida y muerte de Durruti. Grijalbo, Barcelona, 1976.

142 La conocida versión oficial de la detención de los miembros del comité de huelga ("En esta ocasión han caído también algunas arañas de esas que embarcan a la gente mientras que ellos se escondían entre colchones y tinajas de aceite", en "Periódico para todos", 4-X-1917) es repetida aún hoy por algunos sectores, como el citado Joan Ferrer. ("Los detuvieron debajo de las camas y en los tejados, sin pizca de heroicidad».) 
Entre los historiadores socialistas, tampoco hay unanimidad. Para Morato, ${ }^{143}$ "se preparaba una huelga revolucionaria y no de brazos caídos, y en tal sentido habían enviado instrucciones. Hasta en Madrid eran mayoría los obreros que consideraban de este modo el movimiento. Se circularon órdenes, mas no pudieron llegar a todas partes. Aun así la huelga fue pacífica y nada disculpa la ferocidad de la represión ni la saña de la mayor parte de los instrumentos de ella. Fue una huelga materialmente anegada en sangre». En cambio, según Gómez Llorente, ${ }^{144}$ hay que dejar «bien claramente establecido que el movimiento obrero español no se propuso con la huelga de agosto de 1917 hacer la revolución socialista. No se propuso entonces acabar con el sistema capitalistan, pues no se preparó la toma del poder, ni planes de ocupación de centros neurálgicos ni hubo previsión de nuevos gobiernos o autoridades locales y provinciales: "Lo que realmente se proponen los obreros españoles en agosto del 17 es una revolución política de signo democrático... lo que el proletariado exige es civilizar y modernizar el régimen». En lo cual parece coincidir Andrés Saborit, ${ }^{145}$ que asegura que se había preparado un programa realista y regenerador que el pueblo anhelaba se realizase desde el poder, sin cambiar el régimen, si el Rey era inteligente y leal al juramento prestado de identificarse con las aspiraciones nacionales; o contra el régimen, si éste continuaba enemigo irreductible de la voluntad nacional. En suma, "un movimiento que no secundaron con entusiasmo los anarcosindicalistas, hubo traiciones entre los afiliados a la UGT, y cumplieron en líneas generales sus promesas republicanos y reformistas".

Ya en 1917, en Alicante, los medios de comunicación enfocaron la huelga desde sus respectivas posiciones: para el diario gubernamental "El Tiempo" los obreros habian ido a la huelga obligados, sin saber por qué, y se trataba de un movimiento revolucionario que había de resistirse no sólo por el Gobierno, sino

J. J. Morato, o. c., pág. 217.

L. Gómez LloRente, o. c., pág. 258.

La huelga de agosto de 1917, México, 1967. (Citado por David RuIz, El movimiento obrero en Asturias.) 
por todos y cada uno de los ciudadanos; ${ }^{146}$ y afirmaba que los más perjudicados habían sido los obreros mismos, pues habia aumentado el número de empeños en el Monte de Piedad. ${ }^{147}$ Esperaba asimismo "El Tiempo" que el fracaso del movimiento provocase el desprestigio de los sindicatos, y confundiendo la realidad con sus deseos, aseguraba que varias sociedades obreras de Madrid tenían el propósito de desligarse de la UGT y de la Casa del Pueblo.

Para el liberal "El Día» no se podía buscar la libertad y la democracia por medio del motín, el atentado y el crimen; los obreros habían actuado bajo la tiranía del Comité y de los dirigentes obreros, que les habian engañado y arrastrado a una peligrosa aventura. Tras citar también el aumento de los empeños en los Montes de Piedad, "El Día" mostraba su confianza en que, en adelante, y como resultado de la experiencia sufrida, la clase obrera ya no prestase oídos a la "sirena sindicalista». ${ }^{148}$

Para otros periódicos de tipo conservador, también resultaba claro que los obreros habían sido engañados y manipulados por elementos perturbadores, "traficantes indignos, hombres sin escrúpulos ni conciencia, verdugos de sus propios hermanos, mercaderes ambiciosos", ${ }^{149}$ y también insistían en que ellos habian sido los principales perjudicados. ${ }^{150}$

Sin embargo, la más interesante, aunque descabellada, de las interpretaciones sobre el origen de la huelga era la que la ligaba a la polémica entre germanófilos y aliadófilos. Así, para "Diario de Alicante", ${ }^{151}$ la huelga la habían causado los alema-

146 "El Tiempo", 15-VIII-1917: "Todos querían volver al trabajo, dándose cuenta de que el paro perjudicaba principalmente a los obreros, que se ven privados de sus medios de vida" / "El Tiempo", 17-VIII-1917: "Hemos tenido ocasión de hablar con obreros y no han sabido decirnos el por qué del paro generaln.

147 Lo cual, para "El Luchador», no probaba más que el bajo nivel de vida de los obreros.

148 "El Dia», 21, 23 y 24-VIII-1917.

149 ¡Siempre niños... !, en «El Liberal», 25-VIII-1917.

150 «Había que oir las maldiciones y reniegos de las madres de familia hacia las huelgas y paros tan descabellados como el pasado". ("La Correspondencia Alicantina", 23-VIII-1917.)

151 «Diario de Alicante", 23-VIII-1917. 
nes, porque en Alicante habia muchas fábricas francesas, como si no hubiera sucedido absolutamente nada en el resto de España. Postura semejante, aunque opuesta, era la defendida por "Periódico para todos" y "La Correspondencia Alicantina", ambos germanófilos: para el primero, la huelga había sido "el producto de las auríferas arenas del Sena" ${ }^{152}$ y para el segundo, que citaba en su apoyo a parte de la prensa nacional - "El Imparcial", "La Nación" y "La Correspondencia de España»-, la prueba del influjo francés en la huelga era que a Largo Caballero se le habian ocupado, al ser detenido, ochenta mil pesetas en metâlico y un cheque de sesenta mil duros, y a otros detenidos "respetables sumas en billetes del Banco de Francia». ${ }^{153}$

Para el semanario socialista "Trabajo", de Elche, lógicamente, la huelga había sido algo muy positivo y los presos eran "hombres honrados que quieren para su pueblo más bienestar, más libertades y más justicia" ${ }^{154}$ y recordaba una frase de Kropotkin, según la cual "jamás hubo en el mundo insurrección inútil». Una postura semejante adoptó la prensa republicana, cuando pudo hablar, tras el levantamiento de la censura militar: "Los individuos del llamado Comité Revolucionario van a distintos penales; Ios célebres Vivillo y Pelicoco siguen en libertad". ${ }^{155}$

Hubo, sin embargo, unanimidad en la prensa alicantina en atribuir a la huelga un carácter totalmente pacífico y en resaltar siempre el respeto de los huelguistas a la propiedad privada. Veamos algunos ejemplos:

Pero en Alicante, por ejemplo, y en otras partes, los huelguistas, dueños del campo hasta la llegada de la tropa, no cometieron ningún desmán. ${ }^{156}$

"Periódico para todos", 25-VIII-1917. El día 16 había afirmado que el paro era poco oportuno porque "distrae la atención de nuestros gobernantes del gran combate europeo que nos aflige". "La Correspondencia Alicantina", 20-VIII-1917 / "El Día", criticaba estas interpretaciones: "Nadie está para gastar dinero cuando se tienen graves preocupaciones en casan.

154 "Trabajo», 21-X-1917 / Según "El Socialista», 9-XI-1917, "la organización obrera de Alicante escribió una página brillante en la historia del proletariado".

155 «El Luchador», 12-X-1917.

156 "El Luchador», 25-VIII-1917, que lo toma de "El País». 
La huelga general ha sido aquí (en Alicante) pacifica, así como unos días de fiesta que se han tomado los obreros para descansar y para expansionarse. El tumulto callejero ha sido cosa de la chiquillería. ${ }^{157}$

Merece consignarse en honor a la verdad que los revoltosos no cometieron (en Villena) ningún atentado a la propiedad. Durante el día 13, el tren correo de Madrid, que estuvo todo el día sin custodia y llevaba en la ambulancia de Correos una respetable cantidad de pliegos y valores, fue respetado por las turbas. ${ }^{158}$

En Novelda, en ningún momento se llegó al pillaje ni se atentó contra la propiedad privada. ${ }^{159}$

\section{CONCLUSIONES}

En conclusión, en la huelga de agosto de 1917 en la provincia de Alicante se puede apreciar, en primer lugar, una escasa participación de los reformistas y republicanos en los acontecimientos: no eran ni muchos ni demasiado combativos; los más directamente implicados fúeron los de aquellas localidades del Alto y Medio Vinalopó en las que la huelga revistió mayor gravedad; en otros lugares, o bien desaparecieron -caso de Alcoy-, o bien se mantuvieron al margen -en Alicante y Elche, por ejemplo-; el caso de los reformistas detenidos en Jávea no altera este diagnóstico, pues debió de tratarse de un episodio de la lucha entre caciques de la comarca de La Marina, sin repercusiones en la población.

En segundo lugar, no hubo participación destacable de los obreros agrícolas, entonces casi totalmente desorganizados en Alicante: tal vez tuvieron algún papel en Villena, Benejama, Cañada y Sax, pero, en general, puede decirse que, más allá de los núcleos industrializados de la provincia, la huelga no tuvo lugar, permaneciendo en total calma comarcas enteras como el Bajo Segura, La Marina o la Hoya de Castalla.

157

158

159

"La Correspondencia Alicantina", 20-VIII-1917.

La información es oficial, pues la reproducen idénticamente "La Correspondencia Alicantina", 20-VIII-1917, y "Diario de Alicante", 21-VIII-1917. «El Luchador», 6-VI-1918. 
Hubo, en tercer lugar, una reacción unánime y sin fisuras del Ejército y las fuerzas de seguridad en contra de los huelguistas: el aparato coercitivo del Estado funcionó a la perfección, contra lo que los huelguistas - recuérdense los vitores al Ejército en Alcoy - esperaban, probablemente influidos por rumores relativos a la actuación de las Juntas de Defensa y sus contactos con algunos miembros de la Asamblea de Parlamentarios.

Finalmente, faltó un plan de acción entre los huelguistas para "el día siguiente»: en efecto, la huelga parece funcionar bien los primeros momentos, aunque tampoco en ellos se trató de neutralizar los centros neurálgicos del sistema. Pese a la campaña de preparación, no parece que existiesen entre los huelguistas planes concretos, aunque hay que tener en cuenta que la detención, en las primeras horas de la huelga, de los dirigentes obreros más destacados pudo contribuir a esta desorganización. Como sucedió en Elda y en otros lugares, la clase obrera organizada consideró cumplido su papel al cortar las comunicaciones, declarar la huelga en las fábricas e impedir la circulación de vehículos: después, se dispuso a esperar el advenimiento de la República. Así las cosas, resultó bastante fácil a las autoridades "restablecer el orden".

Creemos, pues, que en cierta medida, la huelga de agosto de 1917 fue la culminación de la política llevada a cabo por la Conjunción Republicano-Socialista: es decir, para los dirigentes socialistas más influyentes, encabezados por Besteiro, en tal coyuntura la clase obrera debía limitar su papel a coadyuvar en la toma del poder por una burguesía moderna. Pese a ello, en algunos sectores del proletariado organizado - la CNT e, incluso, parte de la UGT- se pretendió probablemente algo más, una auténtica revolución social. Lo cierto es que el malestar creado entre los trabajadores por los efectos de la Guerra Mundial en su nivel de vida fue utilizado, en esa coyuntura de agosto de 1917, como fuerza de choque para forzar al régimen a modernizarse, pensando que si la monarquía no aceptaba tal evolución, se produciría entonces una revolución democrático-burguesa que daría paso a la República. Así pues, se trataba de un proyecto poco definido y que esperaba demasiado de fuerzas ajenas al proletariado - colaboración de la burguesía moderna y de la pequeña 
burguesia, inhibición del Ejército, etc.- Además, las consignas no fueron, al parecer, explícitas en lo relativo al carácter, revolucionario o pacífico, de la huelga. Pese a todo, este aldabonazo que supuso la huelga general provocó, precisamente, el apuntalamiento del debilitado régimen monárquico por la burguesía catalana y por el Ejército, aterrorizados ambos ante la perspectiva de la revolución social, por lejana que estuviese.

$Y$ aunque, en años inmediatamente posteriores, la huelga de agosto fuese conmemorada entre los trabajadores como un hecho glorioso del proletariado y de carácter revolucionario -aunque identificando siempre la revolución con el derribo de la Monarquía-, ${ }^{160}$ en definitiva, los acontecimientos de 1917 sirvieron de lección: para los sindicalistas, habían sido una prueba más de la "traición de los políticos", por lo que se acentuó su tradicional desconfianza hacia toda "aventura política»; para los socialistas, pese a que no renunciaban al mito de aquellas jornadas de gloria en las que "todo el peso fue para los socialistas", tampoco se trataba de algo a repetir. Se acentuó así el reformismo práctico de muchos socialistas y en los años de la Dictadura, el recuerdo de la huelga de 1917 servirá precisamente de argumento a los sectores más moderados del PSOE y de la UGT para rechazar una alianza con los republicanos ${ }^{161}$ que, curiosamente, tendría, cuando por fin se llevó a cabo, el mismo objetivo que la huelga de 1917: un cambio de régimen para modernizar así a España.

Veánse, por ejemplo, los suplementos de "Trabajo" de fecha 13 y 17-VIII1918, que se conservan en el Archivo Municipal de Elche, sobre la llamada "semana roja" / También, Fecha histórica, en "Trabajo", 13-VIII-1922: "Nuestro gesto de rebeldía, criminalmente reprimido, podia haber ahorrado cinco años de terror; las víctimas de la ley de fugas, los atentados sin responsabilidad, los encarcelamientos y otras mil barbaridades".

161 En "El Mundo Obrero", 3-XI-1929, un joven socialista negaba la acusación que se le hacia al PSOE de colaboracionismo con la Dictadura y afirmaba el carácter republicano del partido. Pero, advertía, "no estamos dispuestos, como en el 17, a sacar las castañas del fuego a nadie». 